\title{
Open Research: Examples of good practice, and resources across disciplines
}

\author{
Authors: Emily K Farran, Priya Silverstein, Aminath A Ameen, Iliana Misheva, \\ Camilla Gilmore. \\ With contributions from (Z-A): Emma Wise, Watt, Becky, Ines Violante, Steven \\ Van Hauwaert, Craig Underwood, Mark Plumbley, Eike Mark Rinke, Tom \\ Pollard, Esther Plomp, Luke Plonsky, Charlotte Pennington, Laura Bowering \\ Mullen, Danielle Kurtin, Neil Chue Hong, Jan Henning Höffler, leuan French, \\ Katie Costello, Gareth Cole, Ben Catt, Peter Barbrook-Johnson, Tibor Auer.
}

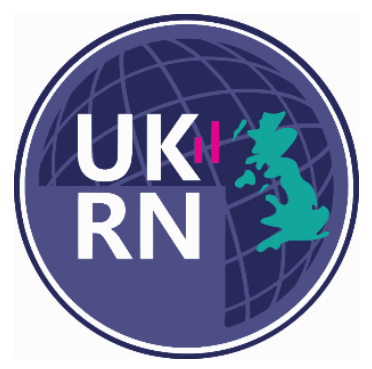

\section{Introduction}

Open research is best described as "an umbrella term used to refer to the concepts of openness, transparency, rigor, reproducibility, replicability, and accumulation of knowledge" (Crüwell et al., 2019, p. 3). Although a lot of open research practices have commonly been discussed under the term "open science", open research applies to all disciplines. If the concept of open research is new to you, it might be difficult for you to determine how you can apply open research practices to your research. The aim of this document is to provide resources and examples of open research practices that are relevant to your discipline. As a starting point, it might be useful to read the UK Reproducibility Network primers (https://www.ukrn.org/primers/), although note that not all will be relevant to all disciplines.

\section{How to use this document}

The contents page displays a list of disciplines and research techniques (e.g., qualitative research, single case study designs) as well as resources that are relevant across all disciplines (e.g., open access repositories). For each of these we have provided an example of how open research is used in that field, and a series of resources. These resources range from research papers about open research, links to websites, how-to guides, to lists of relevant preprint repositories or open access journals. Although not a specific objective, while searching for resources, we also came across discipline specific Open Educational resources. These have also been included. Examples of open research practice and resources are categorised into five colour coded categories: General, Open Data, Open Methods, Open Outputs and Open Education.

It may be useful to start by looking at the "Relevant across multiple disciplines" section to get an overview of open research practices, before going into more specific resources for your overarching field(s) (e.g., Arts and Social Sciences) and then your specific discipline(s) (e.g., History). If your work could fit into multiple disciplines or your exact discipline is not listed here, please use resources from similar/related disciplines. Also, we may have categorised your discipline in a different overarching field to what you're used to (e.g., Psychology can come under social sciences, life sciences, health sciences, etc.), so if you can't find your discipline, try using the search bar.

\section{"As open as possible, as closed as necessary."}

There are circumstances in which research transparency is limited. At the end of the document, you will also find sections on Personal Data, Open Innovation and Co- 
Production. Open research, open innovation and co-production all have a shared end goal, to enable the research to be used by others, with impact for society. However, if your research will produce Intellectual Property (IP), you must talk to your university Intellectual Property office about protecting your research before embarking on any open research practices for your project. Equally, if your research is produced with stakeholders and end users of research, be sure to involve your university legal team before embarking on any open research practices for your project. Finally, research data often contain personal data. This is often the case in the fields of life and health science, and in qualitative data. However, even if the raw data is unsuitable for sharing, the same project might produce other outputs which can be shared and/or datasets that can be anonymised. This must be considered within ethics applications. If your research involves human participants, be sure to involve your university ethics board before embarking on any open sharing of data. More details are provided in the sections on Personal Data, Open Innovation and Co-Production.

\section{How to contribute to this document}

If you have any resources (or entire disciplines!) that you would like to add, or you spot any errors, please fill out the following Google form. New entries will be added annually (last updated October 2022).

https://docs.google.com/forms/d/e/1FAlpQLSfs- 


\section{Contents}

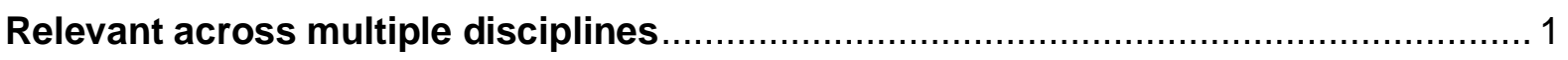

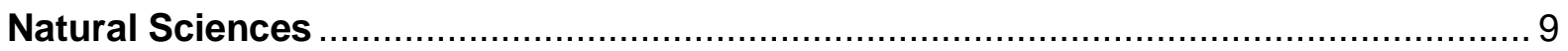

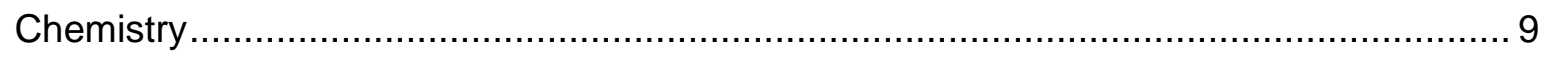

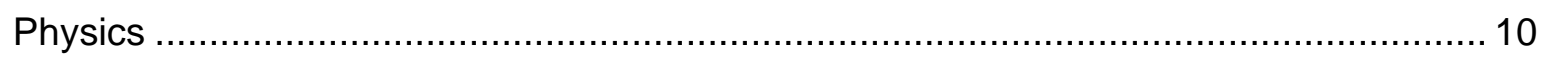

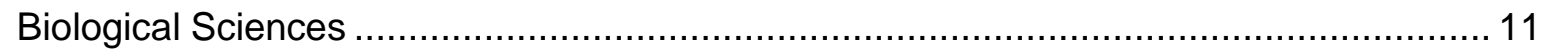

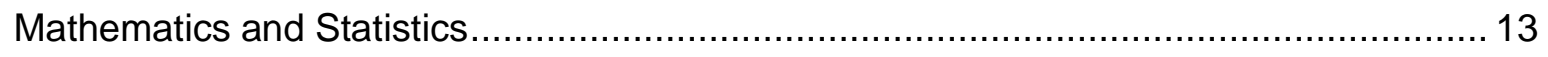

Environmental Sciences, Ecology and Geography ................................................. 14

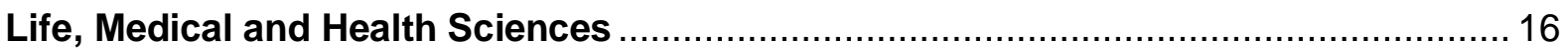

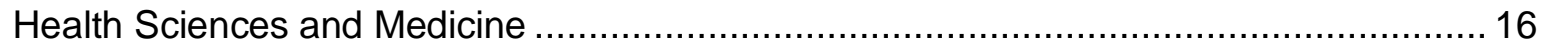

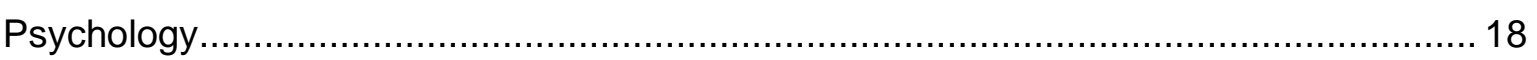

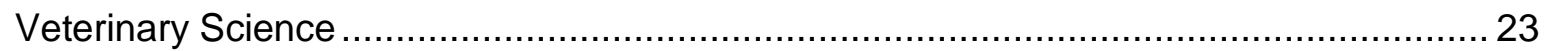

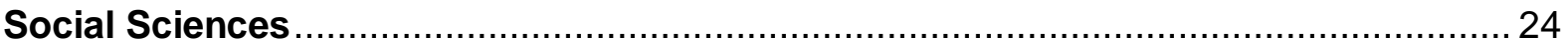

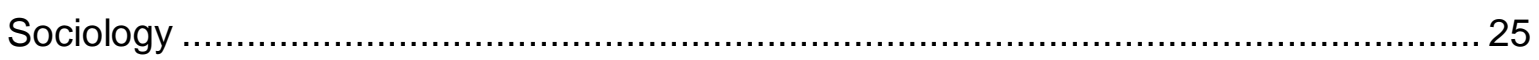

Political Science, Politics and International Studies .................................................. 26

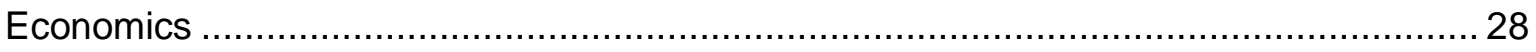

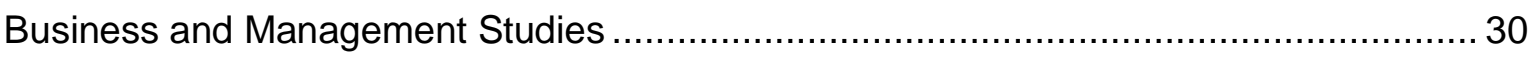

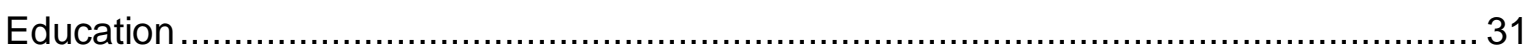

Library and Information Science (including Open Education) …................................. 32

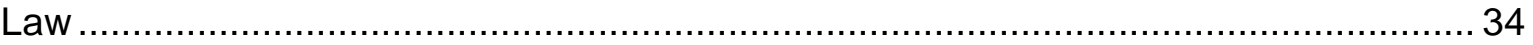

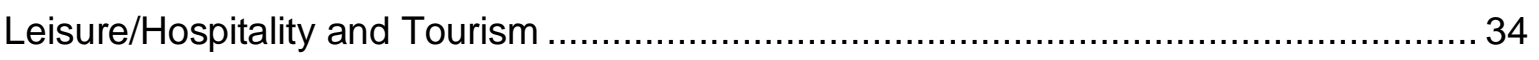

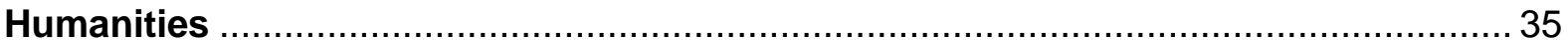

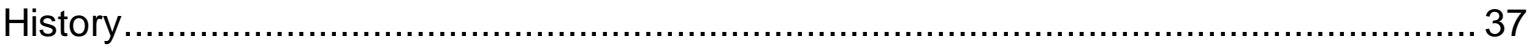

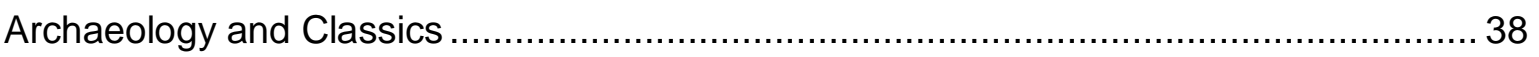

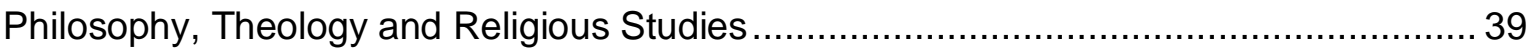

Modern Language, Literature and Linguistics ............................................................. 41

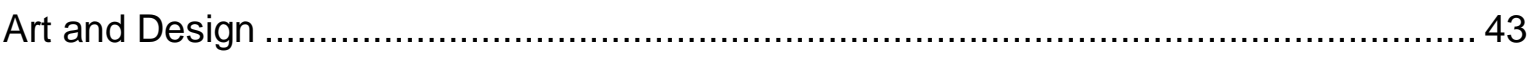

Music, Drama and Performing Arts, Film and Screen Studies ................................... 44

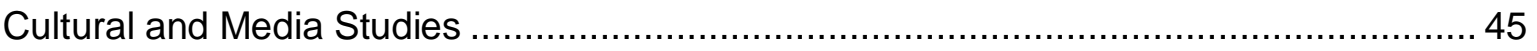

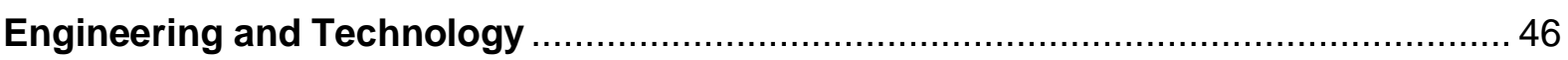

Engineering (including Electrical, Civil, Environmental, Chemical and Mechanical

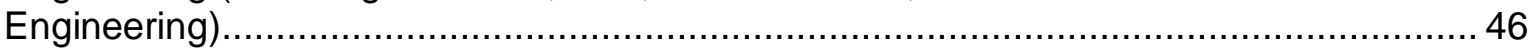

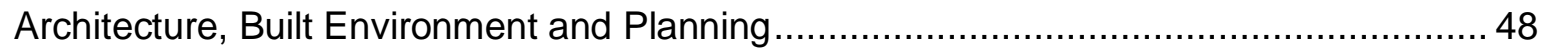

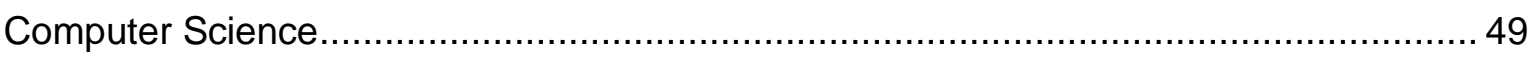

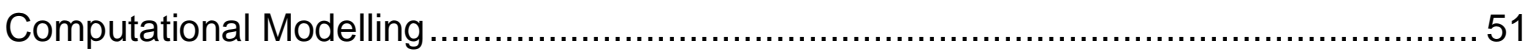

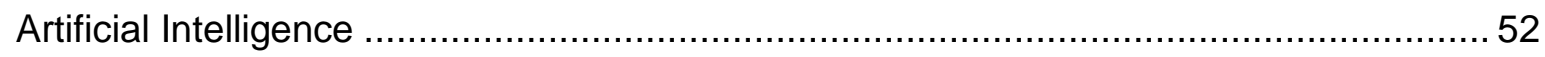

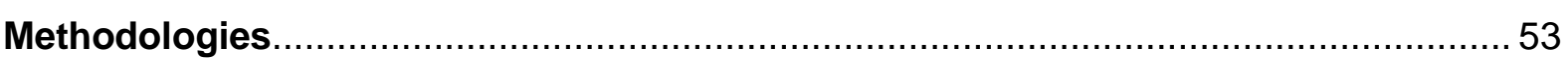

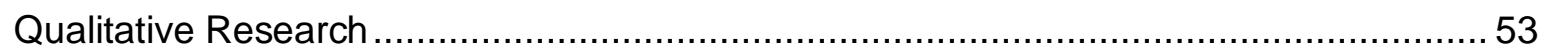

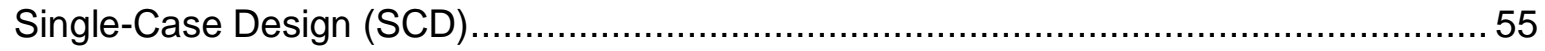


Personal Data.

56

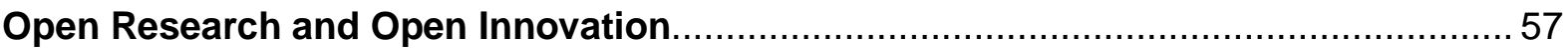

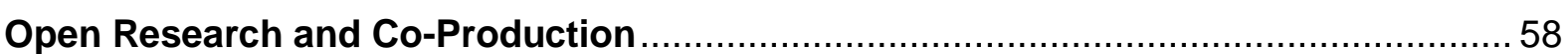




\section{Relevant across multiple disciplines}

Table of resources

\begin{tabular}{|c|c|}
\hline $\begin{array}{l}\text { Transparency } \\
\text { category }\end{array}$ & Resources \\
\hline \multirow[t]{2}{*}{ General: COS } & $\begin{array}{l}\text { Open Science Framework (preprints, pre-registration, sharing data, etc.). } \\
\text { https://osf.io } \\
\text { How to guidance: } \underline{\text { https://osf.io/4znzp/ }}\end{array}$ \\
\hline & $\begin{array}{l}\text { Open Scholarship Knowledge Base. } \\
\text { https://www.oercommons.org/hubs/OSKB }\end{array}$ \\
\hline \multirow[t]{5}{*}{$\begin{array}{l}\text { General: } \\
\text { UKRN primers }\end{array}$} & $\begin{array}{l}\text { UKRN primer, pre-registration and registered reports. } \\
\text { https://osf.io/8v2n7/ }\end{array}$ \\
\hline & $\begin{array}{l}\text { UKRN primer, preprints. } \\
\text { https://osf.io/m4zyh/ }\end{array}$ \\
\hline & $\begin{array}{l}\text { UKRN primer, open access. } \\
\text { https://osf.io/94rsp/ }\end{array}$ \\
\hline & $\begin{array}{l}\text { UKRN primer, open software and code. } \\
\text { https://osf.io/aw9ck/ }\end{array}$ \\
\hline & $\begin{array}{l}\text { UKRN primer, open data. } \\
\text { https://osf.io/wp4zu/ }\end{array}$ \\
\hline \multirow[t]{5}{*}{ General } & $\begin{array}{l}\text { Report and case studies of open data (government report from Open } \\
\text { Research Data Task Force). } \\
\text { https://www.gov.uk/government/publications/open-research-data-task- } \\
\underline{\text { force-final-report }}\end{array}$ \\
\hline & $\begin{array}{l}\text { Summaries of current state of open access / open research across lots } \\
\text { of disciplines. } \\
\text { open-access.network: Open Access in individual disciplines }\end{array}$ \\
\hline & $\begin{array}{l}\text { Baker, M. (2016) 1,500 scientists lift the lid on reproducibility. Nature, } \\
\text { 553, 452-454 } \\
\text { https://doi.org/10.1038/533452a }\end{array}$ \\
\hline & $\begin{array}{l}\text { Project focused on improving communication between researchers in } \\
\text { social sciences and humanities. } \\
\text { https://www.operas.unito.it/ }\end{array}$ \\
\hline & $\begin{array}{l}\text { Reading University Open Research case studies of accessing or } \\
\text { practicing Open Research. } \\
\text { https://www.reading.ac.uk/research/research-environment/open- } \\
\underline{\text { research/open-research-case-studies.aspx }}\end{array}$ \\
\hline
\end{tabular}


University of Surrey Open Research case studies of practicing Open Research

https://www.surrey.ac.uk/library/open-research/open-research-casestudies

Zhu, Y. (2019) Open-access policy and data-sharing practice in UK academia. Journal of Information Science, 46(1), 41-52

https://journals.sagepub.com/doi/full/10.1177/0165551518823174

Portal supporting open science.

https://www.fosteropenscience.eu/

OpenAIRE offers a suite of services designed to facilitate and foster the growth of open research across Europe.

https://www.openaire.eu/

The European Open Science Cloud. For science, technology, the humanities and social sciences. A virtual environment with open services for storage, management, analysis and re-use of research data (for EU member states).

https://www.eosc-portal.eu/

Including a searchable 'marketplace' of open research services.

https://marketplace.eosc-portal.eu/

A series of factsheets about open access, repositories and personal data.

https://www.openaire.eu/openaire-h2020-factsheets

Surrey Reproducibility Society Independent learning resources.

https://osf.io/4ahfw/wiki/home/

Research data policies and support.

https://www.springernature.com/gp/authors/research-data-policy

Legal side of open source.

http://opensource.guide/legal/

Open-source community-driven guide to Open Research.

https://the-turing-way.netlify.app/welcome

Building social and technical bridges to access open research.

https://www.rd-alliance.org/

Allen, C., \& Mehler, D. M. (2019). Open science challenges, benefits and tips in early career and beyond. PLoS Biology, 17(5), e3000246.

https://doi.org/10.1371/journal.pbio.3000587 
Introductory open research online courses.

https://opensciencemooc.eu/

Kowalczyk, O., Lautarescu, A., Blok, E., Dall'Aglio, L., Westwood, S. (2020). What senior academics can do to support reproducible and open research: a short, three-step guide. PsyArXiv.

https://doi.org/10.31234/osf.io/iyfr7

Five things that every researcher should know about open science. https://www.youtube.com/watch?v=0uCG3Fl6ugE\&feature=youtu.be

How to become an Open Science Champion.

https://www.youtube.com/watch?v=IV1aFnPkUSI

A mentoring and training program to become an Open Science Ambassador.

https://openlifesci.org/index\#applications

Reproducibility workshops that raise awareness for open research practices.

https://www.repro4everyone.org/

Collection of resources for researchers interested in Open Science practices

https://how-to-open.science/

How to become more open

https://plos.org/become-more-open/

Passport for Open Science: A guide for PhD students.

https://www.ouvrirlascience.fr/passport-for-open-science-a-practicalguide-for-phd-students/?mc cid=0abeb12a98\&mc eid=3f2684c619

Introduction to Open Access Publishing.

https://www.jisc.ac.uk/guides/an-introduction-to-open-access

Blogpost on 'Becoming a better scientist with open and reproducible research'.

https://lgatto.github.io/open-and-rr-2/

Transitioning to Open Science post Covid-19: 5 Strategies for the Future https://www.research-consulting.com/enabling-a-sustainable-transitionto-open-science-5-strategies-for-the-future/

Glossary of Open Research Terms

https://forrt.org/glossary/ 
Journal club initiative that helps researchers create Open Science journal clubs at their universities

https://reproducibilitea.org/

The RIOT Science Club raises awareness and provides training in Reproducible and Open Science practices.

http://www.riotscience.co.uk/

https://www.youtube.com/c/RIOTScienceClub/videos

The Geneva Workshop on Innovations in Scholarly Communication OA12 (September 2020). Includes discussion about Open Science and its future.

https://oai.events/oai12/

ReproHack. Hackathon where researchers attempt to reproduce published research with publicly available code and data.

https://reprohack.github.io/reprohack-hq/

Octopus. An open database for publishing research, including hypotheses, methods, data and analysis.

https://science-octopus.org/

University of York. Open Research: a Practical Guide

Home - Open Research: a Practical Guide - Subject Guides at University of York

Maarten van Smeden. (2022). A Very Short List of Common Pitfalls in Research Design, Data Analysis, and Reporting. PRiMER.

A Very Short List of Common Pitfalls in Research Design, Data Analysis, and Reporting (stfm.org)

Burgos, D. (2020). Radical Solutions and Open Science. Lecture Notes

In Educational Technology. https://doi.org/10.1007/978-981-15-4276-3

Sarafoglou, A., Kovacs, M., Bakos, B., Wagenmakers, E., \& Aczel, B. (2022). A survey on how preregistration affects the research workflow: better science but more work. Royal Society Open Science, 9(7).

https://doi.org/10.1098/rsos.211997

Gopalakrishna, G., ter Riet, G., Vink, G., Stoop, I., Wicherts, J., \& Bouter, L. (2022). Prevalence of questionable research practices, research misconduct and their potential explanatory factors: A survey among academic researchers in The Netherlands. PLOS ONE, 17(2), e0263023. https://doi.org/10.1371/journal.pone.0263023

de Jonge, H., Cruz, M., \& Holst, S. (2021). Funders need to credit open science. Nature, 599(7885), 372-372. https://doi.org/10.1038/d41586021-03418-1 


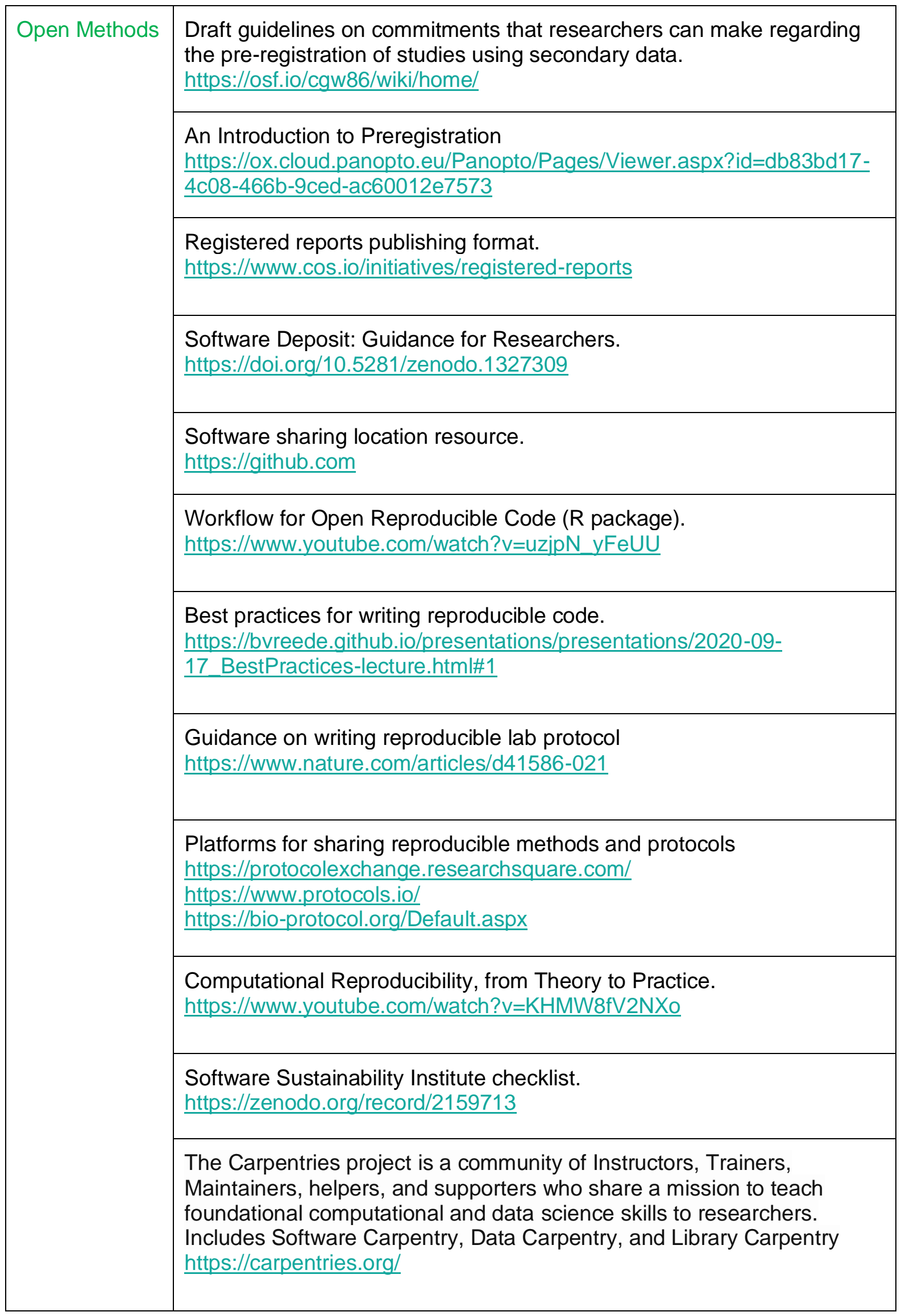




\begin{tabular}{|c|c|}
\hline & $\begin{array}{l}\text { Training materials for researchers. } \\
\text { https://coderefinery.org/ }\end{array}$ \\
\hline & $\begin{array}{l}\text { Open and reproducible research guide. } \\
\text { https://the-turing-way.netlify.app/welcome }\end{array}$ \\
\hline & $\begin{array}{l}\text { Modern vision for peer review } \\
\text { https://medium.com/bits-and-behavior/a-modern-vision-for-peer-review- } \\
\underline{\mathrm{d} 5 \mathrm{f} 73 \mathrm{f0fae} 07}\end{array}$ \\
\hline \multirow[t]{11}{*}{ Open Data } & $\begin{array}{l}\text { In depth details of the principles of FAIR (Findable, Accessible, } \\
\text { Interoperable, Reusable) data. } \\
\text { https://howtofair.dk/ }\end{array}$ \\
\hline & $\begin{array}{l}\text { Case studies of uses of open data. } \\
\text { https://howtofair.dk/how-to-fair/\#case-introductions }\end{array}$ \\
\hline & $\begin{array}{l}\text { Research data management handbook. } \\
\text { https://www.openaire.eu/rdm-handbook }\end{array}$ \\
\hline & $\begin{array}{l}\text { Research data transparency. } \\
\text { https://rmarkdown.rstudio.com/ }\end{array}$ \\
\hline & $\begin{array}{l}\text { Jupyter Notebook: tool for interactively developing and presenting data } \\
\text { science projects. } \\
\text { https://www.dataquest.io/blog/jupyter-notebook-tutorial/ }\end{array}$ \\
\hline & $\begin{array}{l}\text { Binder: allows you to create custom computing environments that can be } \\
\text { shared and used by many remote users. } \\
\text { https://mybinder.readthedocs.io/en/latest/ }\end{array}$ \\
\hline & $\begin{array}{l}\text { Research data repository. } \\
\text { https://www.re3data.org/ }\end{array}$ \\
\hline & $\begin{array}{l}\text { Dataverse. } \\
\text { https://dataverse.harvard.edu/ }\end{array}$ \\
\hline & $\begin{array}{l}\text { Data portal. } \\
\text { https://www.europeandataportal.eu/en }\end{array}$ \\
\hline & $\begin{array}{l}\text { UK Data Service data catalogue. } \\
\text { https://www.ukdataservice.ac.uk/get-data/key-data.aspx }\end{array}$ \\
\hline & $\begin{array}{l}\text { Resource on data sharing and databases. } \\
\text { https://fairsharing.org/ }\end{array}$ \\
\hline
\end{tabular}




\begin{tabular}{|c|}
\hline $\begin{array}{l}\text { Database of example data management plans, and funder requirements } \\
\text { of data management plans (institutional subscription required for full } \\
\text { access). } \\
\text { https://dmponline.dcc.ac.uk/ }\end{array}$ \\
\hline $\begin{array}{l}\text { How to write an article with supporting data. } \\
\text { https://codata.org/initiatives/strategic-programme/codata- } \\
\text { connect/webinar-series-research-skills/webinar-2-writing-an-article-with- } \\
\text { excellent-supporting-data/ }\end{array}$ \\
\hline $\begin{array}{l}\text { Tips for publishing open data and how to use it. } \\
\text { https://theodi.org/ }\end{array}$ \\
\hline $\begin{array}{l}\text { Tool for cleaning up messy data, and for extending and matching data. } \\
\text { https://openrefine.org// }\end{array}$ \\
\hline $\begin{array}{l}\text { Data repositories across fields. } \\
\text { https://www.nature.com/sdata/policies/repositories }\end{array}$ \\
\hline $\begin{array}{l}\text { Digital Curation Centre (https://www.dcc.ac.uk) has a range of resources } \\
\text { from different disciplines related to Research Data Management and } \\
\text { Data lifecycle. } \\
\text { Includes: Case study on data management in Arts and Humanities; tools } \\
\text { for creating data management plans across disciplines; links to } \\
\text { institutional research data management policies including arts-focused } \\
\text { institutions. } \\
\text { https://www.dcc.ac.uk/resources/developing-rdm-services/dmps-arts- } \\
\text { and-humanities } \\
\text { https://www.dcc.ac.uk/guidance/policy/institutional-data-policies }\end{array}$ \\
\hline $\begin{array}{l}\text { Open access digital library. } \\
\text { https://www.loc.gov }\end{array}$ \\
\hline $\begin{array}{l}\text { CODECHECK. Independent review of computations underlying research } \\
\text { articles during their peer review, to support sharing of code and data. } \\
\text { https://f1000research.com/articles/10-253 } \\
\text { https://codecheck.org.uk/ }\end{array}$ \\
\hline $\begin{array}{l}\text { Video discussing data reusability and GDPR } \\
\text { https://www.youtube.com/watch?v=biTlb-As4SU }\end{array}$ \\
\hline $\begin{array}{l}\text { Collection of repositories and databases for open data in different fields } \\
\text { http://oad.simmons.edu/oadwiki/Data repositories }\end{array}$ \\
\hline
\end{tabular}




\begin{tabular}{|c|c|}
\hline & $\begin{array}{l}\text { Hossain, M. A., \& Dwivedi, Y. K. (2016). State-of-the-art in open data } \\
\text { research: Insights from existing literature and a research agenda. } \\
\text { Journal of Organisational Computing and Electronic Commerce, } 26 \text { (1- } \\
\text { 2), 14-40. } \\
\text { https://doi.org/10.1080/10919392.2015.1124007 }\end{array}$ \\
\hline & $\begin{array}{l}\text { Platform that supports the creation of open data } \\
\text { https://frictionlessdata.io/ }\end{array}$ \\
\hline \multirow[t]{9}{*}{ Open Outputs } & $\begin{array}{l}\text { Directories of open access journals across fields. } \\
\text { https://doaj.org/ } \\
\text { http://www.oajse.com/ } \\
\text { http://www.open-science-repository.com/ } \\
\text { https://core.ac.uk/ }\end{array}$ \\
\hline & $\begin{array}{l}\text { Repositories. } \\
\text { https://zenodo.org/ } \\
\text { https://figshare.com/ }\end{array}$ \\
\hline & $\begin{array}{l}\text { Directories of open access books across fields. } \\
\text { https://www.doabooks.org/ } \\
\text { https://www.intechopen.com/ } \\
\text { https://oaister.worldcat.org// } \\
\text { https://archive.org/details/texts }\end{array}$ \\
\hline & $\begin{array}{l}\text { List of preprint repositories. } \\
\text { https://docs.google.com/spreadsheets/d/1zYOy6bcydDZ9G56FKmDzg } \\
\text { pexTarVsJR5hH0KiQGt l/edit\#gid=1494155948 }\end{array}$ \\
\hline & $\begin{array}{l}\text { Repository finder. } \\
\text { https://repositoryfinder.datacite.org/ } \\
\text { https://v2.sherpa.ac.uk/opendoar/ }\end{array}$ \\
\hline & $\begin{array}{l}\text { SSRN is a platform for the dissemination of early-stage research. } \\
\text { https://www.ssrn.com/index.cfm/en/ }\end{array}$ \\
\hline & $\begin{array}{l}\text { First Look is a partnership between SSRN and some of the world's most } \\
\text { influential journals to provide rapid, early and open access to evolving } \\
\text { scholarly research prior to publication. } \\
\text { https://www.ssrn.com/index.cfm/en/first-look/ }\end{array}$ \\
\hline & $\begin{array}{l}\text { Open access in individual disciplines. } \\
\text { open-access.network: Open Access in individual disciplines } \\
\underline{\text { https://portal.issn.org/ }}\end{array}$ \\
\hline & $\begin{array}{l}\text { Journal of Open-Source Software. } \\
\text { https://joss.theoj.org/ }\end{array}$ \\
\hline
\end{tabular}




\begin{tabular}{|c|}
\hline $\begin{array}{l}\text { Journal of Open Research Software Deposit. } \\
\text { https://openresearchsoftware.metajnl.com/ }\end{array}$ \\
\hline $\begin{array}{l}\text { Example of a methods sharing journal. } \\
\text { https://www.journals.elsevier.com/methodsx/ }\end{array}$ \\
\hline $\begin{array}{l}\text { Guidance on how to choose a license for your open project. } \\
\text { https://choosealicense.com/ } \\
\text { https://www.youtube.com/watch?v=y9y8a304fjg }\end{array}$ \\
\hline $\begin{array}{l}\text { Guidance on how to share research. } \\
\text { https://plos.org/resource/how-to-share-your-research/ }\end{array}$ \\
\hline $\begin{array}{l}\text { SciGen. Report is a platform to publish full, partial or failed replications of } \\
\text { articles. } \\
\text { https://scigen.report/ }\end{array}$ \\
\hline $\begin{array}{l}\text { Rescience } C \text { is an open access journal that publishes replicated } \\
\text { research. } \\
\text { http://rescience.github.io/ }\end{array}$ \\
\hline
\end{tabular}

\section{Natural Sciences}

\section{Chemistry}

\section{Examples of open research practices}

Open Data: Lia et al. (2020) (https://doi.org/10.12688/wellcomeopenres.15893.2). The paper is published in Wellcome Open Research (https://wellcomeopenresearch.org/) which is a rapid and transparent publishing platform. Wellcome Open Research supports data citations and peer review reports and follows an open research publishing model which entails publication within days of submission followed by an open invited peer review. All the data used in this paper is openly available with the paper which directs to RCSB Protein Data Bank (https://www.rcsb.org/) and Zenodo (https://zenodo.org/record/3817277) for underlying data and extended data.

Table of resources

\begin{tabular}{|l|l|}
\hline $\begin{array}{l}\text { Transparency } \\
\text { category }\end{array}$ & Resources \\
\hline General & $\begin{array}{l}\text { Presentation about open science in chemistry. } \\
\text { https://www.fosteropenscience.eu/content/what-could-open-science- } \\
\text { really-mean-chemistry }\end{array}$ \\
\cline { 2 - 2 } & $\begin{array}{l}\text { Why chemistry research should be open access. } \\
\text { https://www.springeropen.com/p/chemistry }\end{array}$ \\
\hline
\end{tabular}




\begin{tabular}{|c|c|}
\hline & $\begin{array}{l}\text { Article about open data. } \\
\text { https://www.chemistryworld.com/news/open-data-linked-to-higher- } \\
\text { citations-for-journal-articles/3010723.article }\end{array}$ \\
\hline & $\begin{array}{l}\text { Royal Society of Chemistry often hold open research events, e.g. } \\
\text { https://www.rsc.org/events/detail/42090/open-chemical-science }\end{array}$ \\
\hline & $\begin{array}{l}\text { Royal Society of Chemistry recorded discussion of plan S. } \\
\text { https://youtu.be/isSnSYMpZjY }\end{array}$ \\
\hline \multirow[t]{2}{*}{ Open Methods } & $\begin{array}{l}\text { Slides about open science. } \\
\text { https://www.fosteropenscience.eu/content/what-could-open-science- } \\
\text { really-mean-chemistry }\end{array}$ \\
\hline & $\begin{array}{l}\text { Open-source software lists. } \\
\text { https://awesomeopensource.com/projects/chemistryhttps://www.opench } \\
\text { emistry.org/ }\end{array}$ \\
\hline Open Data & $\begin{array}{l}\text { List of chemistry databases. } \\
\text { https://www.rsc.org/journals-books-databases/databases-literature- } \\
\underline{\text { updates/ }}\end{array}$ \\
\hline \multirow[t]{2}{*}{ Open Outputs } & $\begin{array}{l}\text { Preprint repositories. } \\
\text { https://chemrxiv.org/ } \\
\text { https://ecsarxiv.org }\end{array}$ \\
\hline & $\begin{array}{l}\text { Details of Open Access Journals } \\
\text { open-access.network: Open Access in Chemistry }\end{array}$ \\
\hline
\end{tabular}

\section{Physics}

\section{Examples of open research practices}

Open Methods: Open workflow. For example, "ESCAPE (European Science Cluster of Astronomy and Particle physics ESFRI research infrastructures) brings together the astronomy, astroparticle and particle physics communities. With this, ESCAPE puts together ... projects with aligned challenges of data-driven research, with demonstrated capabilities in addressing various stages of data workflow and concerned with fundamental research through complementary approaches." (https://projectescape.eu/about-us)

Open Data: The Galaxy and Mass Assembly (GAMA) is a "project to exploit the latest generation of ground-based and space-borne survey facilities to study cosmology and galaxy formation and evolution... Using public data, its own campaigns and data sharing with independent survey imaging survey teams, "GAMA is creating an extraordinary multiwavelength photometric and spectroscopic dataset with outstanding values to both the largescale structure and galaxy evolution communities." Details of data releases are provided on the GAMA website.(GAMA | Galaxy And Mass Assembly (gama-survey.org))

Table of resources 


\begin{tabular}{|l|l|}
\hline $\begin{array}{l}\text { Transparency } \\
\text { category }\end{array}$ & Resources \\
\hline General & $\begin{array}{l}\text { Engineering and Physical Sciences Research Council's (EPSRC) } \\
\text { framework policy requires researchers to link supporting data for funded } \\
\text { papers. } \\
\text { https://epsrc.ukri.org/about/standards/researchdata/ }\end{array}$ \\
\hline Open Methods & $\begin{array}{l}\text { Data and software repositories, community science. } \\
\text { https://projectescape.eu/about-us }\end{array}$ \\
\hline Open Data & $\begin{array}{l}\text { Data repository for research conducted at CERN. } \\
\text { http://opendata.cern.ch/ }\end{array}$ \\
\cline { 2 - 3 } & $\begin{array}{l}\text { Collection of open access data repositories } \\
\text { https://www.re3data.org/search? subjects[]=32\%20Physics }\end{array}$ \\
\hline \multirow{2}{*}{ Open Outputs } & $\begin{array}{l}\text { Open access guide. } \\
\text { open-access.network: Open Access in Physics }\end{array}$ \\
\cline { 2 - 3 } & $\begin{array}{l}\text { Sponsoring Consortium for Open Access Publishing in Particle Physics. } \\
\text { http://www.open-science-repository.com/ }\end{array}$ \\
\cline { 2 - 3 } & $\begin{array}{l}\text { Preprint repository. } \\
\text { https://arxiv.org/ } \\
\text { CERn document server (particle physics preprints).//cds.cern.ch/collection/Preprints }\end{array}$ \\
\hline
\end{tabular}

\section{Biological Sciences}

\section{Examples of open research practices}

Open Data: Using and contributing to open data. Examples are reported in Table 1 of Feng et al. (2019), such as: "Species distribution records were collected from the Ocean Biogeographic Information System (OBIS; http://iobis.org, accessed February 2016), from the Global Biodiversity Information Facility (GBIF; http://gbif.org, accessed January 2016), the Reef Life Survey (RLS; http://reeflifesurvey.com, accessed February 2016) and for a few species via personal communications (Bosch et al., 2018)." (From Feng et al (2019). A checklist for maximizing reproducibility of ecological niche models. Nat Ecol Evol 3, 13821395. https://doi.org/10.1038/s41559-019-0972-5)

Open Data: Working alongside 'Open Microscopy', Glencoe Software have developed and adopted Open Microscopy Environment - Next-Generation File Formats (OME-NGFF). This is a new "Cloud-friendly data format for multi-D bioimaging data using... It has been designed from its inception to work with scalable, cloud-based data resources and for public or shared data repositories used for Al training and data publication. There are examples of using OMENGFF for whole slide imaging (as in digital pathology), high content screening and 3D imaging of large tissue samples.". (OME-NGFF in action; Glencoe Software, Inc.) 


\begin{tabular}{|c|c|}
\hline $\begin{array}{l}\text { Transparency } \\
\text { category }\end{array}$ & Resources \\
\hline \multirow[t]{9}{*}{ General } & $\begin{array}{l}\text { MOOC: an introduction to Open Science principles in biomedicine, life } \\
\text { sciences and other related research fields. } \\
\text { https://www.open.edu/openlearncreate/course/view.php?id=4633 }\end{array}$ \\
\hline & $\begin{array}{l}\text { Taylor, B. and Woods, S. (2020) Reflections on the practice of } \\
\text { Responsible (Research and) Innovation in synthetic biology, New } \\
\text { Genetics and Society, 39:2, 127-147, } \\
\text { https://www.tandfonline.com/doi/full/10.1080/14636778.2019.1709431 }\end{array}$ \\
\hline & $\begin{array}{l}\text { Open innovation in the life sciences. Conference, training, public } \\
\text { lectures. } \\
\text { https://www.openinnovationlifesciences.com }\end{array}$ \\
\hline & $\begin{array}{l}\text { Open workshops, seminars, and tools in plant pathology. } \\
\text { https://openplantpathology.org }\end{array}$ \\
\hline & $\begin{array}{l}\text { Open resources about biological sciences to share, exchange expertise. } \\
\text { https://elixir-europe.org/ }\end{array}$ \\
\hline & $\begin{array}{l}\text { Mentoring and training program for Open Science ambassadors. } \\
\text { https://openlifesci.org/ }\end{array}$ \\
\hline & $\begin{array}{l}\text { Open, digital and collaborative space for biological and medical } \\
\text { research. Workflows, data, workshops, funding. } \\
\text { https://www.eosc-life.eu }\end{array}$ \\
\hline & $\begin{array}{l}\text { Agricultural and food sciences community. Scope: to provide access to } \\
\text { publications, research data, projects and software related to the field. } \\
\text { Includes the following tabs of sharable resources: publications, research } \\
\text { data, software, other research. } \\
\text { https://beta.aginfra.openaire.eu }\end{array}$ \\
\hline & $\begin{array}{l}\text { Munafò, M., Noble, S., Browne, W. et al. Scientific rigor and the art of } \\
\text { motorcycle maintenance. Nat Biotechnol 32, 871-873 (2014). } \\
\text { https://www.nature.com/articles/nbt.3004 }\end{array}$ \\
\hline \multirow[t]{2}{*}{ Open Methods } & $\begin{array}{l}\text { Presentation on open workflows and tools. } \\
\text { https://www.fosteropenscience.eu/content/life-sciences-and-open- } \\
\underline{\text { science-workflows-and-tools }}\end{array}$ \\
\hline & $\begin{array}{l}\text { Recorded talk on preprints. } \\
\text { https://www.youtube.com/watch?index=5\&list=PLPkfOHxsjx2gDqOooyw } \\
\text { ho7uvw800pfxq2\&v=SWDKyEZ4Gel }\end{array}$ \\
\hline
\end{tabular}




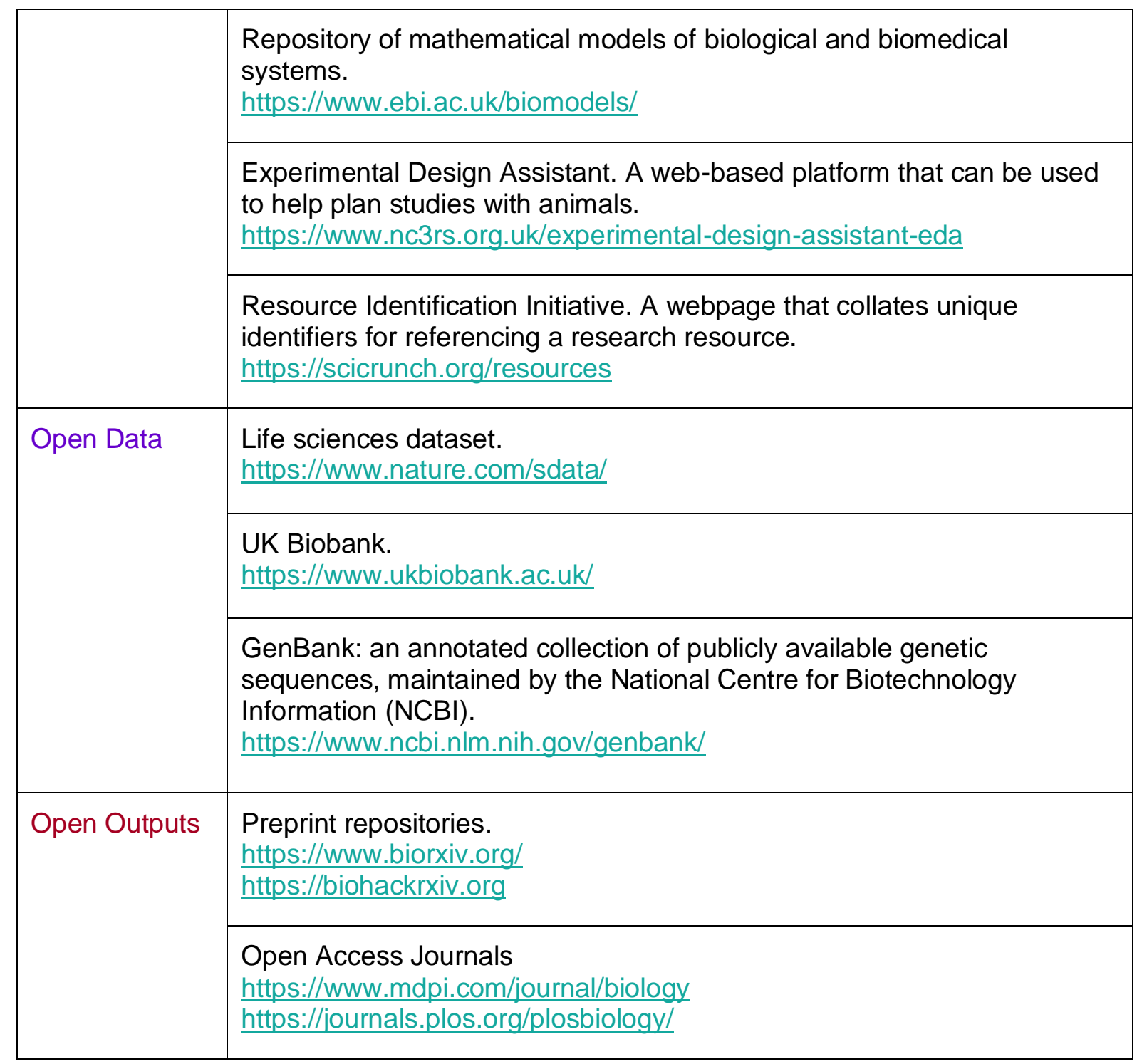

\section{Mathematics and Statistics}

Examples of open research practices

Open Methods: Jan Kokko and colleagues have been exploring the likelihood-free inference method, a methodological branch of statistics which is commonly used within simulationbased models in disciplines such as population genetics and astronomy. In their recent work (2019), they introduce an open-access Python adaptation of the Likelihood-Free Inference by Ratio Estimation (LFIRE), abbreviated as PYLFIRE. Based on penalised logistic regression, PYLFIRE can be accessed via the open-source inference software ELFI. (https://wellcomeopenresearch.org/articles/4-197/v1)

Table of resources 


\begin{tabular}{|c|c|}
\hline \multirow[t]{2}{*}{ General } & $\begin{array}{l}\text { Database and support of open software, open access publishing, and } \\
\text { reproducible research in statistics. } \\
\text { http://www.foastat.org/ }\end{array}$ \\
\hline & $\begin{array}{l}\text { Calin-Jageman, R.J. \& Cumming, G. (2019) The New Statistics for } \\
\text { Better Science: Ask How Much, How Uncertain, and What Else Is } \\
\text { Known, The American Statistician, 73:sup1, 271-280. } \\
\text { https://doi.org/10.1080/00031305.2018.1518266 }\end{array}$ \\
\hline Open Methods & $\begin{array}{l}\text { Open statistical software. } \\
\text { https://jasp-stats.org/ } \\
\text { https://www.jamovi.org/ } \\
\text { https://www.r-project.org/ }\end{array}$ \\
\hline \multirow[t]{3}{*}{ Open Data } & $\begin{array}{l}\text { Open dataset with journal articles. } \\
\text { https://rss.onlinelibrary.wiley.com/hub/datasets }\end{array}$ \\
\hline & $\begin{array}{l}\text { Database of worldbank open data. } \\
\text { https://data.worldbank.org/ }\end{array}$ \\
\hline & $\begin{array}{l}\text { Centre for Vision, Speech and Signal Processing, University of Surrey } \\
\text { Datasets. } \\
\text { https://cvssp.org/ }\end{array}$ \\
\hline \multirow[t]{2}{*}{ Open Outputs } & $\begin{array}{l}\text { Preprint repository. } \\
\text { https://arxiv.org// }\end{array}$ \\
\hline & $\begin{array}{l}\text { Open Access Journals } \\
\text { https://www.mdpi.com/journal/mathematics } \\
\text { https://www.springeropen.com/p/mathematics }\end{array}$ \\
\hline
\end{tabular}

\section{Environmental Sciences, Ecology and Geography}

\section{Examples of open research practices}

Open Data: Dr Jon Blower is the Chief Technology Officer at the Institute for Environmental Analytics (IEA) and contributed to developing an open source software named ncWMS (https://reading-escience-centre.github.io/ncwms/) which allows users to visualise and explore large-scale environmental datasets online. Data providers in the US and the European Commission's Copernicus Marine Service adapted the software to create an interactive webbased 'quick-look' tool which allows users to browse through their data holdings online. With the distribution of the software source code for free (available on GitHub at https://github.com/Reading-eScience-Centre/ncwms) it allows reuse, modification and redistribution of the code that has been used in developing cutting-edge environmental data products and services. (https://www.reading.ac.uk/research/research-environment/openresearch/open-research-case-studies.aspx)

Table of resources 


\begin{tabular}{|c|c|}
\hline $\begin{array}{l}\text { Transparency } \\
\text { category }\end{array}$ & Resources \\
\hline \multirow[t]{4}{*}{ General } & $\begin{array}{l}\text { Community dashboard for EuroMarine (a consortium of } 56 \text { research and } \\
\text { academic organisations) and monitoring dashboard for marine research } \\
\text { initiatives, including infrastructures (e.g. EMBRC and EMSO), advisory } \\
\text { boards (e.g. Marine Boards and ICES), and transnational funding bodies } \\
\text { (e.g. JPI-Oceans and Tara Foundation). Includes the following tabs of } \\
\text { sharable resources: publications, research data, software, other } \\
\text { research. } \\
\text { https://mes.openaire.eu/ }\end{array}$ \\
\hline & $\begin{array}{l}\text { Conservation of marine resources for sustainable development. The } \\
\text { Fisheries and Aquaculture community focus on resources (documents, } \\
\text { data, codes...) which have been produced in the framework of projects } \\
\text { (H2020, FP7...) related to the domain of fisheries and aquaculture. } \\
\text { Includes the following tabs of sharable resources: publications, research } \\
\text { data, software, other research. } \\
\text { https://fam.openaire.eu/ }\end{array}$ \\
\hline & $\begin{array}{l}\text { The UN Sustainable Development Solutions Network (SDSN). SDSN } \\
\text { mobilizes global scientific and technological expertise to promote } \\
\text { practical solutions for sustainable development. Developed TReNDs } \\
\text { (Thematic Research Network on Data and Statistics, that aims to create } \\
\text { high quality, replicable and open data. } \\
\text { https://www.unsdsn.org/ } \\
\text { https://www.sdsntrends.org/ }\end{array}$ \\
\hline & $\begin{array}{l}\text { Guide on open educational resources in geography. } \\
\text { https://libguides. humboldt.edu/openedu/geog }\end{array}$ \\
\hline Open Methods & $\begin{array}{l}\text { Reichman, O. J., Jones, M. B., \& Schildhauer, M. P. (2011). Challenges } \\
\text { and Opportunities of Open Data in Ecology. Science, 331, 703-705. } \\
\text { https://doi.org/10.1126/science.1197962 }\end{array}$ \\
\hline \multirow[t]{3}{*}{ Open Data } & $\begin{array}{l}\text { Open access journals. } \\
\text { https://rgs-ibg.onlinelibrary.wiley.com/loi/20544049 } \\
\text { https://www.longdom.org/geography-natural-disasters.html }\end{array}$ \\
\hline & $\begin{array}{l}\text { Paper on barriers to open data in environmental sciences. } \\
\text { https://journals.plos.org/plosone/article?id=10.1371/journal.pone.014669 } \\
\underline{5}\end{array}$ \\
\hline & $\begin{array}{l}\text { Culina, A., Baglioni, M., Crowther, T.W. et al. Navigating the unfolding } \\
\text { Open Data landscape in ecology and evolution. Nat Ecol Evol 2, 420- } \\
426 \text { (2018). Includes Table } 1 \text { : A list of the main data discovery sources } \\
\text { for searching for EcoEvo data in one interface, and for later accessing } \\
\text { the data of interest. } \\
\text { https://doi.org/10.1038/s41559-017-0458-2 }\end{array}$ \\
\hline
\end{tabular}




\begin{tabular}{|l|l|}
\hline Open Outputs & $\begin{array}{l}\text { Preprint repositories. } \\
\text { https://eartharxiv.org/ } \\
\text { https://ecoevorxiv.org }\end{array}$ \\
\cline { 2 - 3 } & $\begin{array}{l}\text { Directory of open access journals. } \\
\text { https://bit.ly/39r3kQ4 }\end{array}$ \\
\cline { 2 - 3 } & $\begin{array}{l}\text { Open access repository for geography. } \\
\text { http://www.open-science-repository.com/journal-of-geography.html }\end{array}$ \\
\cline { 2 - 3 } & $\begin{array}{l}\text { Open access journals. } \\
\text { https://rgs-ibg.onlinelibrary.wiley.com/loi/20544049 } \\
\text { https://www.longdom.org/geography-natural-disasters.html }\end{array}$ \\
\hline
\end{tabular}

\section{Life, Medical and Health Sciences}

\section{Health Sciences and Medicine}

\section{Examples of open research practices}

Open Methods: The "Unseating Big Pharma" case study involves collaboration from 15 countries with the aim to end the legacy of big pharma. Scientists are working together in an effort to show how an open-science model can end dependency on manufacturers and benefit vaccine equity. (Unseating big pharma: the radical plan for vaccine equity (nature.com))

Open Data: "Carsten Brink works with sensitive personal data in the field of radiotherapy for cancer patients. Having FAIR (Findable, Accessible, Interoperable, Reusable) data is essential to the researchers in his field, because they need interoperable data from a large number of patients to predict outcomes. The researchers in his field used to gather data from many different institutes and pool them in one physical location to run models. But, because they need to preserve the patients' confidentiality, physically moving the data is a legally complicated task. Instead, they now work with distributed learning, which allows them to analyse data at other institutes without having to physically move them."

(https://howtofair.dk/how-to-fair/\#health-science)

Table of resources

\begin{tabular}{|l|l|}
\hline $\begin{array}{l}\text { Transparency } \\
\text { category }\end{array}$ & Resources \\
\hline General & $\begin{array}{l}\text { Kostkova, P., Brewer, H., de Lusignan, S., Fottrell, E., Goldacre, B., } \\
\text { Hart, G., ... and Ross, E. (2016). Who owns the data? Open Data for } \\
\text { healthcare. Frontiers in public health, 4. } \\
\text { https://www. frontiersin.org/articles/10.3389/fpubh.2016.00007/full }\end{array}$ \\
\hline
\end{tabular}




\begin{tabular}{|c|c|}
\hline & $\begin{array}{l}\text { Guides for MRC funded studies. } \\
\text { https://mrc.ukri.org/research/policies-and-guidance-for- } \\
\text { researchers/open-research-data-clinical-trials-and-public-health- } \\
\text { interventions/ } \\
\text { https://mrc.ukri.org/research/policies-and-guidance-for- } \\
\text { researchers/open-access-policy/ }\end{array}$ \\
\hline & $\begin{array}{l}\text { Guide for DHSC and NIHR funded studies. } \\
\text { https://www.nihr.ac.uk/documents/nihr-open-access-policy/12251 }\end{array}$ \\
\hline & $\begin{array}{l}\text { Allen C, Mehler, D.M.A. (2019) Open science challenges, benefits and } \\
\text { tips in early career and beyond. PLoS Biol 17(5): e3000246. } \\
\text { https://doi.org/10.1371/journal.pbio.3000246 }\end{array}$ \\
\hline & $\begin{array}{l}\text { Case studies: working with transcript data; working with sensitive survey } \\
\text { data. } \\
\text { https://howtofair.dk/how-to-fair/\#humanities }\end{array}$ \\
\hline & $\begin{array}{l}\text { STEM Podcast about Open Pharma } \\
\text { Open Pharma - driving positive change in the communication of pharma- } \\
\text { sponsored research: Dr Joana Osório (buzzsprout.com) }\end{array}$ \\
\hline & $\begin{array}{l}\text { Kwasnicka, D., Keller, J., Perski, O., Potthoff, S., ten Hoor, G., \& } \\
\text { Ainsworth, B. et al. (2022). White Paper: Open Digital Health - } \\
\text { accelerating transparent and scalable health promotion and } \\
\text { treatment. Health Psychology Review, } 1-17 . \\
\text { https://doi.org/10.1080/17437199.2022.2046482 }\end{array}$ \\
\hline \multirow[t]{5}{*}{ Open Methods } & $\begin{array}{l}\text { Best Practice for Mental Health Data Science: Checklist } \\
\text { https://mhdss.ac.uk/best-practice-mental-health-data-science }\end{array}$ \\
\hline & $\begin{array}{l}\text { Best Practice for Mental Health Data Science: case studies } \\
\text { https://mhdss.ac.uk/case-studies }\end{array}$ \\
\hline & $\begin{array}{l}\text { UKRN primer, pre-registration and registered reports. } \\
\text { https://www.ukrn.org/primers/ }\end{array}$ \\
\hline & $\begin{array}{l}\text { PROSPERO: Registration for systematic reviews with a health-related } \\
\text { outcome. } \\
\text { https://www.crd.york.ac.uk/PROSPERO/\#aboutpage }\end{array}$ \\
\hline & $\begin{array}{l}\text { Protocols: An online platform for developing and sharing reproducible } \\
\text { methods. } \\
\text { https://www.protocols.io }\end{array}$ \\
\hline Open Data & $\begin{array}{l}\text { Open access dataset. } \\
\text { https://data.england.nhs.uk/dataset }\end{array}$ \\
\hline
\end{tabular}




\begin{tabular}{|c|c|}
\hline & $\begin{array}{l}\text { Link for list of dataset archives. } \\
\text { https://library.bath.ac.uk/research-data/finding-data/health-medicine }\end{array}$ \\
\hline & $\begin{array}{l}\text { Collection of physiological data and software. } \\
\text { https://fairsharing.org/biodbcore-000488/. }\end{array}$ \\
\hline \multirow[t]{3}{*}{ Open Outputs } & $\begin{array}{l}\text { Preprint repositories. } \\
\text { https://www.medrxiv.org } \\
\text { https://biohackrxiv.org } \\
\text { https://osf.io/preprints/nutrixiv }\end{array}$ \\
\hline & $\begin{array}{l}\text { Medicine and Health sciences preprint repository. } \\
\text { https://www.medrxiv.org/ }\end{array}$ \\
\hline & $\begin{array}{l}\text { Open Access Journals } \\
\text { https://bmjopen.bmj.com// } \\
\text { https://journals.Iww.com/md-journal/pages/openaccess.aspx } \\
\underline{\text { https://journals.plos.org/plosmedicine/ }}\end{array}$ \\
\hline
\end{tabular}

\section{Psychology}

\section{Examples of open research practices}

Open Methods: Hoch, O'Grady and Adolph (2019) studied locomotion exploration in infants and found their movement to be instigated by the journey of exploration instead of a particular destination (https://onlinelibrary.wiley.com/doi/abs/10.1111/desc.12740). Their data were obtained from Datavyu (http://datavyu.org/), an open-source video coding and data visualization software which incorporates machine learning algorithms that can be used to annotate videos. It also generates paths taken by individuals as well as identifying people in videos which allows behaviour coding inputs to be conducted in real time. Datavyu has the aim of making behavioural data accessible to increase transparency in research and to instigate the use of videos as raw data. By using openly shared videos for data and documentation, the preserved data create an opportunity to ask new research questions and accelerate progress in the field.

Open Methods: The Many Babies project (https://manybabies.github.io/) aims to use an open approach to research into early development. The project works collaboratively with labs around the world to make all key project decisions (e.g., the research question, data collection, and the analysis). Their first project explored infants' preferences for infant-directed speech, compared to adult-directed speech (https://manybabies.github.io/MB1/). The study involved 69 laboratories, from 16 countries, with a total of 2,329 infants studied, with each lab using one of three methods to measure the infants' discrimination: the head-turn preference, central fixation, or eye-tracking. Through collaboration, this project was able to replicate a well-known finding from developmental research, in infants around the world. The materials used in this study and the data collected are all openly accessible on GitHub (https://github.com/manybabies/mb1-analysis-public) and the Open Science Framework (https://osf.io/re95x/). The collaborative projects undertaken by the Many Babies Project allow standardized replication of developmental research around the world whilst being as open and transparent as possible. 
Open Methods and Open Data: PLAY (Play \& Learning Across a Year) is a project that aims to explore infants and their mother's natural behaviours in their homes, across 50 universities in the United States. All materials, home visit protocols and the video and questionnaire data collected are all openly available on their website (https://www.play-project.org/index.html).

Open Data: Anne Urai focuses on the neural basis of decision-making across mammalian species, the interaction between learning and perception, and the neural basis of cognitive aging. The International Brain Laboratory (IBL, https://www.internationalbrainlab.com/) is a collaboration of $\sim 20$ laboratories worldwide. Its researchers are dedicated to standardizing mouse decision-making behavior, coordinating measurements of neural activity across the brain, and using theoretical approaches to formalize the neural computations that support decision-making. In contrast to traditional neuroscientific practice, in which individual laboratories each probe different behaviors and record from a few select brain areas, IBL aims to deliver a standardized, high-density approach to behavioral and neural assays. This approach relies on a highly distributed, collaborative network of $\sim 50$ researchers - postdocs, graduate students, and scientific staff - who coordinate the intellectual, administrative, and sociological aspects of the project. IBL has a data portal that provides tools and solutions they adopted and developed at IBL which are open-sourced and accessible on GitHub.

\section{Table of resources}

\begin{tabular}{|c|c|}
\hline $\begin{array}{l}\text { Transparency } \\
\text { category }\end{array}$ & Resources \\
\hline \multirow[t]{5}{*}{ General } & $\begin{array}{l}\text { Hong. M. and Moran, A. (2019). An introduction to open science. How to } \\
\text { incorporate best practices into your research, Psychological Science } \\
\text { Agenda APA. } \\
\text { https://www.apa.org/science/about/psa/2019/02/open-science }\end{array}$ \\
\hline & $\begin{array}{l}\text { Nosek, B. A. (2014, February 28). Improving my lab, my science with the } \\
\text { open science framework. APS Observer, } 27(3) \text {. } \\
\text { https://www.psychologicalscience.org/observer/improving-my-lab-my- } \\
\text { science-with-the-open-science-framework }\end{array}$ \\
\hline & $\begin{array}{l}\text { Klein, O., Hardwicke, T. E., Aust, F., Breuer, J., ... Frank, M. C. (2018). } \\
\text { A Practical Guide for Transparency in Psychological Science. } \\
\text { Collabra:Psychology, 4(1): } 20 . \\
\text { https://doi.org/10.1525/collabra. } 158\end{array}$ \\
\hline & $\begin{array}{l}\text { Dashboard resource containing neuroscience research outputs and } \\
\text { brain imaging databases. } \\
\text { https://ni.openaire.eu/ }\end{array}$ \\
\hline & $\begin{array}{l}\text { Crüwell, S., van Doorn, J., Etz, A., Makel, M. C., Moshontz, H., } \\
\text { Niebaum, J. C., ... Schulte-Mecklenbeck, M. (2019). Seven easy steps } \\
\text { to open science: An annotated reading list. Zeitschrift für Psychologie, } \\
\text { 227(4), 237-248. } \\
\text { https://econtent.hogrefe.com/doi/10.1027/2151-2604/a000387 }\end{array}$ \\
\hline
\end{tabular}


Kathawalla, U. K., Silverstein, P., \& Syed, M. (2021). Easing into open science: A guide for graduate students and their advisors. Collabra: Psychology, 7(1). https://doi.org/10.1525/collabra.18684

Nosek, B. A., Alter, G., Banks, G. C., Borsboom, D., Bowman, S. D., Breckler, S. J., ... and Contestabile, M. (2015). Promoting an open research culture. Science, 348(6242), 1422-1425.

https://doi.org/10.1126/science.aab2374

Baldwin, J. R., Pingault, J. B., Schoeler, T., Sallis, H. M., \& Munafò, M. R. (2022). Protecting against researcher bias in secondary data analysis: challenges and potential solutions. European Journal of Epidemiology, 37(1), 1-10. https://doi.org/10.1007/s10654-021-00839-0

Baldwin, J. R., Pingault, J. B., Schoeler, T., Sallis, H. M., \& Munafò, M. R. (2022). Protecting against researcher bias in secondary data analysis: challenges and potential solutions. European Journal of Epidemiology, 37(1), 1-10. https://doi.org/10.1007/s10654-021-00839-0

Duncan, G. J., Engel, M., Claessens, A., \& Dowsett, C. J. (2014). Replication and robustness in developmental research. Developmental Psychology, 50(11), 2417-2425. https://doi.org/10.1037/a0037996

Davis-Kean, P. E., \& Ellis, A. (2019). An overview of issues in infant and developmental research for the creation of robust and replicable science. Infant Behavior and Development, 57, 101339.

https://doi.org/10.1016/j.infbeh.2019.101339

Syed, M. (2022), Special issue on reliability of infant research. Inf Child Dev, 31: e2382. https://doi.org/10.1002/icd.2382

Educational Psychology in the Open Science Era

https://www.tandfonline.com/toc/hedp20/56/2?nav=tocList

Open Research Practices in Autism Research

https://sites.google.com/york.ac.uk/openautismresearch/home?authuser $=\underline{0}$

Introduction to Open Science in Psychology Reading List https://t.co/NAkOaCh7oz

Lakens, D. (2019). The value of preregistration for psychological science: A conceptual analysis. Japanese Psychological Review, 62(3), 221-230. Retrieved 21 September 2022, from

https://www.jstage.jst.go.jp/article/sjpr/62/3/62 221/ pdf.

Kalandadze, T., \& Hart, S. (2022). Open developmental science: An overview and annotated reading list. Infant And Child Development. https://doi.org/10.1002/icd.2334 


\begin{tabular}{|c|c|}
\hline & $\begin{array}{l}\text { Farran, E. K., \& Scerif, G. (2022). Genetic syndromes, } \\
\text { neuroconstuctivism, and replicable research; challenges and future } \\
\text { directions. Infant and Child Development. e2307. } \\
\text { https://doi.org/10.1002/icd.2307 }\end{array}$ \\
\hline & $\begin{array}{l}\text { Pownall, M., Azevedo, F., Aldoh, A., Elsherif, M., Vasilev, M., \& } \\
\text { Pennington, C. et al. (2021). Embedding open and reproducible science } \\
\text { into teaching: A bank of lesson plans and resources. Scholarship Of } \\
\text { Teaching And Learning In Psychology. } \\
\text { https://doi.org/10.1037/stl0000307 }\end{array}$ \\
\hline \multirow[t]{10}{*}{ Open Methods } & $\begin{array}{l}\text { Task repositories. } \\
\text { https://expfactory.github.io/ }\end{array}$ \\
\hline & $\begin{array}{l}\text { Neuroimaging tool repository. } \\
\text { https://www. nitrc.org }\end{array}$ \\
\hline & $\begin{array}{l}\text { NIRO: Guideline resource for systematic reviews. } \\
\text { https://osf.io/erkwa/ }\end{array}$ \\
\hline & $\begin{array}{l}\text { Pipeline tools. Automatic Analysis, NiPype. } \\
\text { Neuroimaging in Python - Pipelines and Interfaces - nipy pipeline and } \\
\text { interfaces package (nipype.readthedocs.io) }\end{array}$ \\
\hline & $\begin{array}{l}\text { Mullen, L. B. (2019, February } 7) \text {. Scholarly Communication and Open } \\
\text { Access in Psychology: Current Considerations for Researchers. } \\
\text { PsyArXiv. } \\
\text { https://doi.org/10.31234/osf.io/2d7um }\end{array}$ \\
\hline & $\begin{array}{l}\text { Havron, N., Bergmann, C., \& Tsuji, S. (2020). Preregistration in infant } \\
\text { research-A primer. Infancy, 25(5), 734-754. } \\
\underline{\text { https://doi.org/10.1111/infa.12353 }}\end{array}$ \\
\hline & $\begin{array}{l}\text { Flake, J., \& Fried, E. (2020). Measurement Schmeasurement: } \\
\text { Questionable Measurement Practices and How to Avoid } \\
\text { Them. Advances In Methods And Practices In Psychological } \\
\text { Science, 3(4), 456-465. } \\
\text { https://doi.org/10.1177/2515245920952393 }\end{array}$ \\
\hline & $\begin{array}{l}\text { Hobson, H., Poole, D., Pearson, A., \& Fletcher-Watson, S. (2022). } \\
\text { Opening up autism research: Bringing open research methods to our } \\
\text { field. Autism, 26(5), 1011-1013. } \\
\text { https://doi.org/10.1177/13623613221105385 }\end{array}$ \\
\hline & $\begin{array}{l}\text { Govaart, G., Schettino, A., Helbling, S., Mehler, D., Ngiam, W., \& } \\
\text { Moreau, D. et al. (2022). EEG ERP Preregistration Template. } \\
\text { https://doi.org/10.31222/osf.io/4nvpt }\end{array}$ \\
\hline & $\begin{array}{l}\text { Schroeder, P., Artemenko, C., Kosie, J., Cockx, H., Stute, K., \& Pereira, } \\
\text { J. et al. (2022). Using preregistration as a tool for transparent fNIRS } \\
\text { study design. https://doi.org/10.31222/osf.io/zfawx }\end{array}$ \\
\hline
\end{tabular}




\begin{tabular}{|c|c|}
\hline & $\begin{array}{l}\text { Petersen, I., Apfelbaum, K., \& McMurray, B. (2022). Adapting open } \\
\text { science and pre-registration to longitudinal research. Infant And Child } \\
\text { Development. } \underline{\text { https://doi.org/10.1002/icd.2315 }}\end{array}$ \\
\hline & $\begin{array}{l}\text { Kwasnicka, D., Keller, J., Perski, O., Potthoff, S., ten Hoor, G., \& } \\
\text { Ainsworth, B. et al. (2022). White Paper: Open Digital Health - } \\
\text { accelerating transparent and scalable health promotion and } \\
\text { treatment. Health Psychology Review, 1-17. } \\
\text { https://doi.org/10.1080/17437199.2022.2046482 }\end{array}$ \\
\hline \multirow[t]{10}{*}{ Open Data } & $\begin{array}{l}\text { Open platform for sharing MRI, MEG, EEG, iEEG, and ECoG data. } \\
\text { https://openneuro.org }\end{array}$ \\
\hline & $\begin{array}{l}\text { Factsheet on balancing open data with data protection of personal data. } \\
\text { https://www.openaire.eu/factsheet-personal-data/view- } \\
\text { document? Itemid= }\end{array}$ \\
\hline & $\begin{array}{l}\text { UK data service list of longitudinal cohort study data. } \\
\text { https://www.ukdataservice.ac.uk/get-data/key-data/cohort-and- } \\
\text { longitudinal-studies.aspx }\end{array}$ \\
\hline & $\begin{array}{l}\text { Twins Early Development Study (TEDS) data. } \\
\text { http://www.teds.ac.uk/researchers/teds-data-access-policy }\end{array}$ \\
\hline & $\begin{array}{l}\text { Repository for unthresholded statistical maps, parcellations, and atlases } \\
\text { of the brain. } \\
\text { https://neurovault.org/ }\end{array}$ \\
\hline & $\begin{array}{l}\text { Open video data software. } \\
\text { https://datavyu.org }\end{array}$ \\
\hline & $\begin{array}{l}\text { Databrary supports data sharing of video and audio recordings among } \\
\text { researchers in the behavioural, social, educational, developmental, } \\
\text { neural, and computer sciences. } \\
\text { https://nyu.databrary.org/ }\end{array}$ \\
\hline & $\begin{array}{l}\text { TalkBank is a data repository of } 14 \text { research areas, focusing on spoken } \\
\text { language } \\
\text { https://talkbank.org/ }\end{array}$ \\
\hline & $\begin{array}{l}\text { Meyer, M. (2018). Practical Tips for Ethical Data Sharing. Advances In } \\
\text { Methods And Practices In Psychological Science, 1(1), 131-144. } \\
\text { https://doi.org/10.1177/2515245917747656 }\end{array}$ \\
\hline & $\begin{array}{l}\text { Data archive and repository for Psycholinguistics } \\
\text { The Language Archive (mpi.nl) }\end{array}$ \\
\hline Open Outputs & $\begin{array}{l}\text { Preprint repository. } \\
\text { https://psyarxiv.com }\end{array}$ \\
\hline
\end{tabular}




\begin{tabular}{|l|l|}
\hline & $\begin{array}{l}\text { Guide to licensing your work on PsyArXiv. } \\
\text { http://blog.psyarxiv.com/2018/05/14/licensing-work-psyarxiv/ }\end{array}$ \\
\cline { 2 - 3 } $\begin{array}{l}\text { Syed, M. (2020, May 7). Managing Preprints across the Publication } \\
\text { Pipeline. Get Syeducated. } \\
\text { https://getsyeducated.blogspot.com/2020/05/managing-preprints-across- } \\
\text { publication.html }\end{array}$ \\
\hline
\end{tabular}

\section{Veterinary Science}

\section{Examples of open research practices}

Open Methods: https://www.surrey.ac.uk/news/training-scientists-use-genomics-programs Dr Arnoud van Vliet has been addressing issues scientists encounter when completing genomics data analyses. Without a doubt, anyone who works with materials from other laboratories (ranging from cell lines, reagents, and computer data) will have been frustrated by missing information, errors and things that just don't work at another location. Many software programs 'penalise' a mistake with a cryptic and unhelpful error message and call on other software packages that aren't installed by default. The outputs can also be incompatible with downstream software. To remedy this, Arnoud designed an online course using short video tutorials to teach scientists how to use these software programs at their own speed.

The user has access to:

- A virtual Linux computer that they can install on their own Windows or Mac laptops, with relatively modest hardware requirements. It comes with installation and usage instructions and contains all the required software and practice data. It's also suitable for the users' own applications later.

- Instruction videos (recorded on Zoom) for the nine different steps.

- Two additional videos explaining how to work with Linux.

- A wash-up session at the end.

Table of resources

\begin{tabular}{|l|l|}
\hline $\begin{array}{l}\text { Transparency } \\
\text { category }\end{array}$ & Resources \\
\hline General & $\begin{array}{l}\text { Diederich, K., Schmitt, K., Schwedhelm, P., Bert, B., \& Heinl, C. (2022). } \\
\text { A guide to open science practices for animal research. PLOS } \\
\text { Biology, 20(9), e3001810. https://doi.org/10.1371/journal.pbio.3001810 }\end{array}$ \\
\hline Open Methods & $\begin{array}{l}\text { Resources required - please complete the Google form (link provided in } \\
\text { the introduction) if you can input here. }\end{array}$ \\
\hline Open Data & $\begin{array}{l}\text { Animal research and testing. Workflow checklist in Table 1 } \\
\text { Smith, A. J., Clutton, R. E., Lilley, E., Hansen, K. E. A., and Brattelid, T. } \\
\text { (2018). PREPARE: guidelines for planning animal research and testing. } \\
\text { Laboratory Animals, 52(2), 135-141. } \\
\text { https://doi.org/10.1177/0023677217724823 }\end{array}$ \\
\hline
\end{tabular}




\begin{tabular}{|c|c|}
\hline & $\begin{array}{l}\text { Open data in veterinary science. } \\
\text { https://towardsdatascience.com/data-in-veterinary-animal-data-abound- } \\
\text { 8d8ba92bbdbc }\end{array}$ \\
\hline & $\begin{array}{l}\text { Open data on global animal disease. } \\
\text { https://empres-i.review.fao.org/\#/ }\end{array}$ \\
\hline & $\begin{array}{l}\text { Animal tracking data website. } \\
\text { https://www.zoatrack.org }\end{array}$ \\
\hline & $\begin{array}{l}\text { Open datasets/repositories. } \\
\text { https://www.journals.elsevier.com/research-in-veterinary- } \\
\text { science/mendeley-data } \\
\text { https://www.movebank.org/cms/movebank-main }\end{array}$ \\
\hline Open Outputs & $\begin{array}{l}\text { Open access journals. } \\
\text { https://www.frontiersin.org/journals/veterinary-science } \\
\text { https://onlinelibrary.wiley.com/journal/20531095 } \\
\text { https://publons.com/journal/41890/open-access-journal-of-veterinary- } \\
\text { science-research/ } \\
\text { https://www.innovationinfo.org/veterinary-science-and-research } \\
\text { https://www.degruyter.com/view/journals/ovs/ovs-overview.xml }\end{array}$ \\
\hline & $\begin{array}{l}\text { Paper on avoiding predatory open access journals. } \\
\text { https://doi.org/10.3389/fvets.2015.00022 }\end{array}$ \\
\hline
\end{tabular}

\section{Social Sciences}

General case studies and resources for social sciences are found in humanities section as some are relevant to both social science and humanities.

Table of resources

\begin{tabular}{|l|l|}
\hline $\begin{array}{l}\text { Transparency } \\
\text { category }\end{array}$ & Resources \\
\hline General & $\begin{array}{l}\text { Data Preservation Alliance for the Social Sciences. } \\
\text { http://www.data-pass.org }\end{array}$ \\
\cline { 2 - 3 } & $\begin{array}{l}\text { A Bibliography on Open Science in the Social Sciences (Made by Nate } \\
\text { Breznau) } \\
\text { https://www.zotero.org/groups/2608283/open science readings }\end{array}$ \\
\cline { 2 - 2 } & $\begin{array}{l}\text { Guide to Data Access and Research Transparency in Social Sciences } \\
\text { https://www.dartstatement.org/ }\end{array}$ \\
\hline
\end{tabular}




\begin{tabular}{|c|c|}
\hline Open Methods & $\begin{array}{l}\text { Guidelines for building transparency into observational social science } \\
\text { research. } \\
\text { https://www.sciencedirect.com/science/article/abs/pii/S01651765183012 } \\
77 \text { ?via\%3Dihub }\end{array}$ \\
\hline \multirow[t]{3}{*}{ Open Data } & $\begin{array}{l}\text { Open access datasets. } \\
\text { https://www.oecd-ilibrary.org } \\
\text { http://www.data-pass.org/ }\end{array}$ \\
\hline & $\begin{array}{l}\text { Guidance on sharing data, code and replicating. } \\
\text { https://social-science-data-editors.github.io/guidance/ }\end{array}$ \\
\hline & $\begin{array}{l}\text { Ball, R., \& Medeiros, N. (2012). Teaching Integrity in Empirical } \\
\text { Research: A Protocol for Documenting Data Management and Analysis. } \\
\text { The Journal of Economic Education, 43(2), 182-189. } \\
\text { https://doi.org/10.1080/00220485.2012.659647 }\end{array}$ \\
\hline \multirow[t]{2}{*}{ Open Outputs } & $\begin{array}{l}\text { List of open access journals in social sciences. } \\
\text { https://simonbatterbury.wordpress.com/2015/10/25/list-of-decent-open- } \\
\text { access-journals/ }\end{array}$ \\
\hline & $\begin{array}{l}\text { Resource library. } \\
\text { https://www.bitss.org/resource-library/ }\end{array}$ \\
\hline
\end{tabular}

\section{Sociology}

\section{Examples of open research practices}

Open Data: "Make all the materials associated with a research paper or book available online. This means data, methodological steps, analyses and software code...Even if you do not share data, you can build an open workflow from the beginning that allows others to understand every step of the data generating process (Steinhardt 2018)...Some forms of qualitative research, for example those involving grounded theory and interpretivist methods, require decisions during the research process that cannot be foreseen. This uncertainty can be outlined in a pre-registration stating explicitly when flexibility is and is not admissible (Haven and Grootel 2019)." (From Breznau (2019, September 21). The Future of Sociology Depends on Open Science. https://doi.org/10.31235/osf.io/d37be)

Table of resources

\begin{tabular}{|l|l|}
\hline $\begin{array}{l}\text { Transparency } \\
\text { category }\end{array}$ & Resources \\
\hline General & $\begin{array}{l}\text { Breznau, N. (2019, September 21). The Future of Sociology Depends on } \\
\text { Open Science. } \\
\text { https://doi.org/10.31235/osf.io/d37be }\end{array}$ \\
\hline
\end{tabular}




\begin{tabular}{|l|l|}
\hline \multirow{3}{*}{ Open Methods } & $\begin{array}{l}\text { Breznau, N. (2021). Does Sociology Need Open Science? Societies, } \\
11(1), 9 . \\
\text { https://doi.org/10.3390/soc11010009 }\end{array}$ \\
& $\begin{array}{l}\text { Open access resources. } \\
\text { https://researchguides.uoregon.edu/sociology/openaccess }\end{array}$ \\
\cline { 2 - 3 } & $\begin{array}{l}\text { Materials for a Crowdsourced Replication Initiative } \\
\text { https://osf.io/bs46f/ }\end{array}$ \\
\hline Open Data & $\begin{array}{l}\text { Databases. } \\
\text { http://gss.norc.org/get-the-data } \\
\text { https://search.datacite.org/ }\end{array}$ \\
\hline Open Outputs & $\begin{array}{l}\text { Preprint repository. } \\
\text { https://osf.io/preprints/socarxiv }\end{array}$ \\
\cline { 2 - 2 } & $\begin{array}{l}\text { Open Access Journals } \\
\text { https://journals.sagepub.com/home/soc } \\
\frac{\text { https://www.frontiersin.org/journals/sociology\# }}{\text { https://onlinelibrary.wiley.com//journal/14684446 }}\end{array}$ \\
\hline
\end{tabular}

\section{Political Science, Politics and International Studies}

Examples of open research practices

Open Data: Transparency International (https://www.transparency.org/en/) is a global movement which advocates against corruption through research and campaigning and promotes transparency and accountability through all levels across all sectors of the society. Their publications are open access and include research papers, reports, policy reports which provide specific data for countries and activities, as well as case studies. Toolkits and guides are also available to be used for anti-corruption activities. For example, the Exporting Corruption Progress Report 2020 (https://www.transparency.org/en/publications/exportingcorruption-2020) focuses on foreign bribery focusing on enforcement levels across different countries and how it is affected during the COVID-19 pandemic.

Table of resources

\begin{tabular}{|l|l|}
\hline $\begin{array}{l}\text { Transparency } \\
\text { Category }\end{array}$ & Resources \\
\hline General & $\begin{array}{l}\text { Overview guide on open access in Political Science. } \\
\text { open-access.network: Open Access in Political Science }\end{array}$ \\
\cline { 2 - 2 } & $\begin{array}{l}\text { Article about open research. } \\
\text { https://www.samuelmoore.org/2019/07/16/why-open-science-is-actually- } \\
\text { pretty-good-politics/ }\end{array}$ \\
\hline
\end{tabular}




\begin{tabular}{|c|c|}
\hline & $\begin{array}{l}\text { Elman, C., Kapiszewski, D., and Lupia, A. (2018). Transparent social } \\
\text { inquiry: implications for political science. Annual Review of Political } \\
\text { Science. } \\
\text { https://www.annualreviews.org/doi/10.1146/annurev-polisci-091515- } \\
\underline{025429}\end{array}$ \\
\hline & $\begin{array}{l}\text { Journal Editors Transparency Statement (JETS). } \\
\text { https://politicalbehavior.wordpress.com/2015/11/11/statement-on-da-rt- } \\
\text { and-the-jets/ }\end{array}$ \\
\hline & $\begin{array}{l}\text { Move towards open access in Politics. } \\
\text { https://scholarlykitchen.sspnet.org/2019/12/16/politics-and-open-access/ }\end{array}$ \\
\hline & $\begin{array}{l}\text { Symposium on 'Opening Political Science'. , A collection of seven short } \\
\text { articles on open research in political and other social science } \\
\text { https://www.cambridge.org/core/journals/ps-political-science-and- } \\
\text { politics/special-collections/opening-political-science }\end{array}$ \\
\hline & $\begin{array}{l}\text { Kapiszewski, D., and Karcher, S. (2019). Transparency in Practice in } \\
\text { Qualitative Research. PS: Political Science \& Politics, 1-7. } \\
\text { https://doi.org/10.33774/apsa-2019-if2he-v2 }\end{array}$ \\
\hline & $\begin{array}{l}\text { Wuttke, A. (2018). Why Too Many Political Science Findings Cannot Be } \\
\text { Trusted and What We Can Do About It: A Review of Meta-Scientific } \\
\text { Research and a Call for Academic Reform. Polit Vierljahresschr, 60:1- } \\
19 . \\
\text { https://t.co/CBYPKp3kTa?amp=1 }\end{array}$ \\
\hline Open Methods & $\begin{array}{l}\text { Open Methods Framework for open observational science. } \\
\text { https://osf.io/preprints/metaarxiv/udfs9/ }\end{array}$ \\
\hline & $\begin{array}{l}\text { Approaches to Open Research for Researchers Using Qualitative } \\
\text { Methods } \\
\text { https://doi.org/10.33774/apsa-2019-if2he-v2 }\end{array}$ \\
\hline Open Data & $\begin{array}{l}\text { Harvard dataverse is an open access data repository. It holds open } \\
\text { access data, associated with Research and Politics, an open access } \\
\text { publication, published by Sage. } \\
\text { https://dataverse.harvard.edu/dataverse/researchandpolitics }\end{array}$ \\
\hline & $\begin{array}{l}\text { Research guide for finding datasets. } \\
\text { Databases - Political Science \& International Relations - LibraryGuides } \\
\text { at Creighton University }\end{array}$ \\
\hline & $\begin{array}{l}\text { Open political science datasets. } \\
\text { https://www.poliscidata.com/pages/internationalRelations.php }\end{array}$ \\
\hline
\end{tabular}




\begin{tabular}{|c|c|}
\hline & $\begin{array}{l}\text { Open public policy digital publication resource. } \\
\text { https://www.openaccessgovernment.org }\end{array}$ \\
\hline & $\begin{array}{l}\text { Open access Political Science articles. } \\
\text { https://www.cambridge.org/core//ournals/british-journal-of-political- } \\
\text { science/open-access } \\
\underline{\text { https://link.springer.com/search?search-within=Journal\&facet-journal- }} \\
\underline{\mathrm{id}=41304 \& \text { package=openaccessarticles }}\end{array}$ \\
\hline & $\begin{array}{l}\text { Human Rights dataset. } \\
\text { http://www.humanrightsdata.com/p/data-documentation.html }\end{array}$ \\
\hline \multirow[t]{5}{*}{ Open Outputs } & $\begin{array}{l}\text { Political Research Exchange (PRX) offers a dynamic platform to } \\
\text { advance research, innovation and debate across the breadth of political } \\
\text { science. With significant subsidies on the normal upfront costs of Open } \\
\text { Access, PRX signals a commitment of the European Consortium for } \\
\text { Political Research as a scholarly association to forging a cogent path for } \\
\text { the research community at this crucial juncture when academic } \\
\text { publishing is becoming fundamentally transformed. } \\
\text { https://www.tandfonline.com/action/journallnformation?show=aimsScope } \\
\text { \&journalCode=prxx20 }\end{array}$ \\
\hline & $\begin{array}{l}\text { Preprint repositories. } \\
\text { https://preprints.apsanet.org/engage/apsa/public-dashboard } \\
\text { https://osf.io/preprints/socarxiv } \\
\text { https://mediarxiv.org/discover } \\
\text { https://www.gesis.org/en/ssoar/home }\end{array}$ \\
\hline & $\begin{array}{l}\text { Open access journals for Political Science. } \\
\text { https://www.longdom.org/political-sciences-public-affairs.html } \\
\text { https://www.degruyter.com/view/journals/openps/openps-overview.xml }\end{array}$ \\
\hline & $\begin{array}{l}\text { Open access journals for Politics. } \\
\text { https://www.cogitatiopress.com/politicsandgovernance } \\
\underline{\text { https://journals.sagepub.com/home/rap }}\end{array}$ \\
\hline & $\begin{array}{l}\text { Open access journal for International Studies. } \\
\text { https://www.jois.eu } \\
\text { https://www.tandfonline.com/loi/cisp20 } \\
\text { https://academic.oup.com/ia }\end{array}$ \\
\hline $\begin{array}{l}\text { Open } \\
\text { Education }\end{array}$ & $\begin{array}{l}\text { Open access book for research methods. } \\
\text { https://ipsrm.com/ }\end{array}$ \\
\hline
\end{tabular}

\section{Economics}

\section{Examples of open research practices}

Open Data: Macroeconomics and studies of international trade require open data sharing and collaboration because informed outcomes require both multiple data sources and equal insights on the policy constraints for each national economy (https://op.europa.eu/s/oGPn). In line with this, there are open access reports on economic change and international trade 
available (https://ec.europa.eu/info/business-economy-euro en) as well as open datasets (https://www.wto.org/index.htm).

Table of resources

\begin{tabular}{|c|c|}
\hline $\begin{array}{l}\text { Transparency } \\
\text { category }\end{array}$ & Resources \\
\hline \multirow[t]{6}{*}{ General } & $\begin{array}{l}\text { Camerer, C. F., Dreber, A., Forsell, E., Ho, T.-H., Huber, J., } \\
\text { Johannesson, M., et al. (2016). Evaluating replicability of laboratory } \\
\text { experiments in economics. Science, 351(6280), 1433-1436. } \\
\text { https://doi.org/10.1126/science.aaf0918 }\end{array}$ \\
\hline & $\begin{array}{l}\text { Christensen, Garret, and Edward Miguel. 2018. "Transparency, } \\
\text { Reproducibility, and the Credibility of Economics Research." Journal of } \\
\text { Economic Literature, 56(3), 920-80. } \\
\text { https://doi.org/10.1257/jel.20171350 }\end{array}$ \\
\hline & $\begin{array}{l}\text { Hamermesh, D. S. (2007). Replication in Economics. Canadian Journal } \\
\text { of Economics, 40(3), 715-733. } \\
\text { https://doi.org/10.1111/j.1365-2966.2007.00428.x }\end{array}$ \\
\hline & $\begin{array}{l}\text { McCullough. B. D. (2009). Open Access Economics Journals and the } \\
\text { Market for Reproducible Economic Research. Economic Analysis and } \\
\text { Policy, 39(1), 117-126. } \\
\text { https://doi.org/10.1016/S0313-5926(09)50047-1 }\end{array}$ \\
\hline & $\begin{array}{l}\text { Vilhuber, L. (2020). Reproducibility and Replicability in } \\
\text { Economics. Harvard Data Science Review, 2(4). } \\
\text { Reproducibility and Replicability in Economics · Issue 2.4, Fall } 2020 \\
\text { (mit.edu) }\end{array}$ \\
\hline & $\begin{array}{l}\text { Legrand, N. (2022). "The empirical relevance of the competitive storage } \\
\text { model" by Cafiero et al. (2011): Replication, robustness, and } \\
\text { extension. Applied Economic Perspectives And Policy. } \\
\text { https://doi.org/10.1002/aepp. } 13282\end{array}$ \\
\hline Open Methods & $\begin{array}{l}\text { Miguel, E., Camerer, C., Casey, K., Cohen, J., Esterling, K. M., Gerber, } \\
\text { A., ... and Laitin, D. (2014). Promoting transparency in social science } \\
\text { research. Science, 343(6166), 30-31. } \\
\text { https://doi.org/10.1126/science.1245317 }\end{array}$ \\
\hline \multirow[t]{2}{*}{ Open Data } & $\begin{array}{l}\text { Databases. } \\
\text { https://www.data-archive.ac.uk } \\
\text { https://www.economicsnetwork.ac.uk/data sets }\end{array}$ \\
\hline & $\begin{array}{l}\text { Journal of Applied Econometrics Data Archive } \\
\text { http://qed.econ.queensu.ca/jae/ }\end{array}$ \\
\hline
\end{tabular}




\begin{tabular}{|l|l|}
\hline \multirow{2}{*}{ Open Outputs } & $\begin{array}{l}\text { Certification Agency for Scientific Code and Data } \\
\text { https://www.cascad.tech }\end{array}$ \\
\hline $\begin{array}{l}\text { Preprint repositories. } \\
\text { http://www.repec.org } \\
\text { https://www.econstor.eu/dspace/ }\end{array}$ \\
\cline { 2 - 2 } $\begin{array}{l}\text { National Bureau of Economics Research publications, data, videos. } \\
\text { https://www.nber.org/papers?page=1\&perPage=50\&sortBy=public date }\end{array}$ \\
\cline { 2 - 2 } & $\begin{array}{l}\text { Wiki-Based Project with Access to Data, Resources and Replications for } \\
\text { Empirical Articles } \\
\text { https://replication.uni-goettingen.de/wiki/index.php/Main Page }\end{array}$ \\
\hline
\end{tabular}

\section{Business and Management Studies}

\section{Examples of open research practices}

"There are now thousands of examples of companies having used open government data as a key business asset that have been documented by the Open Data 500, the Open Data Impact Map, the ExploraLatam, and other studies. These projects have illustrated that companies use open government data for business optimisation, for developing new products and services, or for a combination of the two...Data collaboratives represent an emerging model of public-private partnership within which various actors across sectors exchange data and pool analytical expertise...Research partnerships [are an example of date collaboratives], in which corporations share data with universities and other research organisations to map weather patterns and natural resources, for example."

(From https://www.stateofopendata.od4d.net/chapters/stakeholders/private-sector.html)

Table of resources

\begin{tabular}{|l|l|}
\hline $\begin{array}{l}\text { Transparency } \\
\text { category }\end{array}$ & Resources \\
\hline General & $\begin{array}{l}\text { S. A. Francisco. (2020). Open Science: Reflections on its Implications for } \\
\text { Publishing Business Journals. Revista Administração Em Diálogo, 22. 1- } \\
\begin{array}{l}7 . \\
\text { Doi:10.23925/2178-0080.2020v22i3.50675 }\end{array}\end{array}$ \\
\cline { 2 - 3 } & $\begin{array}{l}\text { H. C. Martins. (2019). The importance of Open Science in Business } \\
\text { research. RAC: Revista de Administraçāo Contemporânea.24(1). } \\
\text { Doi: } 10.1590 / 1982-7849 \text { rac2020190380 }\end{array}$ \\
\cline { 2 - 3 } & $\begin{array}{l}\text { Blog about using open data in business. } \\
\text { http://blog.ukdataservice.ac.uk/how-can-open-data-benefit-business/ }\end{array}$ \\
\hline Open Methods & $\begin{array}{l}\text { Open-source management tool. } \\
\text { http://orchardcollaboration.com/ }\end{array}$ \\
\hline
\end{tabular}




\begin{tabular}{|c|c|}
\hline & $\begin{array}{l}\text { O’Boyle, E. H., Banks, G. C., \& Gonzalez-Mulé, E. (2017). The Chrysalis } \\
\text { Effect: How Ugly Initial Results Metamorphosize Into Beautiful } \\
\text { Articles. Journal of Management, 43(2), 376- } \\
\text { 399. https://doi.org/10.1177/0149206314527133 }\end{array}$ \\
\hline \multirow[t]{2}{*}{ Open Data } & $\begin{array}{l}\text { Data management tools/software. } \\
\text { https://www.cubrid.org/ } \\
\text { https://mariadb.org/ } \\
\text { https://firebirdsql.org/ }\end{array}$ \\
\hline & $\begin{array}{l}\text { The value of open data in the private sector. } \\
\text { https://www.stateofopendata.od4d.net/chapters/stakeholders/private- } \\
\text { sector.html }\end{array}$ \\
\hline \multirow[t]{3}{*}{ Open Outputs } & $\begin{array}{l}\text { Open access journals. } \\
\text { https://sobiad.org/international-journal-of-business-and-management- } \\
\begin{array}{l}\text { studies/ } \\
\text { http://www.macrothink.org/journal/index.php/csbm/index }\end{array} \\
\text { https://www.abacademies.org/journals/business-studies-journal- } \\
\text { home.html } \\
\text { https://fbj.springeropen.com }\end{array}$ \\
\hline & $\begin{array}{l}\text { Archives. } \\
\text { https://escientificpublishers.com/es-business-management-and- } \\
\underline{\text { accounting-studies }}\end{array}$ \\
\hline & $\begin{array}{l}\text { Open access case studies. } \\
\text { https://open.umn.edu/opentextbooks/textbooks/the-sustainable- } \\
\text { business-case-book } \\
\text { https://library.seu.edu/OA/case-studies }\end{array}$ \\
\hline
\end{tabular}

\section{Education}

\section{Examples of open research practices}

Open Methods and Open Outputs: The Education Endowment Foundation funds Randomised Controlled Trials of educational interventions following a set of principles to ensure rigorous, high quality evaluations. Interventions are conducted by independent evaluators rather than the team that developed the intervention. All trials are registered and the evaluation protocol (including power analysis) is published in advance. All trial findings are published on the EEF website, regardless of the outcome of the trial.

Table of resources

\begin{tabular}{|l|l|}
\hline $\begin{array}{l}\text { Transparency } \\
\text { category }\end{array}$ & Resources \\
\hline General & $\begin{array}{l}\text { Education Researchers for Open Science (EROS) is an open science } \\
\text { working group in the Department of Education at the University of York } \\
\text { who have compiled a selected list of freely available tools and resources } \\
\text { that can help researchers understand and adopt open practices. } \\
\text { https://www.york.ac.uk/education/research/eros/ }\end{array}$ \\
\hline
\end{tabular}




\begin{tabular}{|c|c|}
\hline & $\begin{array}{l}\text { Van der Zee, T., and Reich, J. (2018). Open education science. AERA } \\
\text { Open, 4(3). } \\
\text { https://journals.sagepub.com/doi/10.1177/2332858418787466 }\end{array}$ \\
\hline Open Methods & $\begin{array}{l}\text { ManyClasses is a collaborative research project investigating the } \\
\text { generalizability of educational interventions in real classrooms. } \\
\text { https://www.manyclasses.org }\end{array}$ \\
\hline \multirow[t]{2}{*}{ Open Data } & $\begin{array}{l}\text { Open data outlets. } \\
\text { https://opendataimpactmap.org/education } \\
\text { https://www.ukdataservice.ac.uk/get-data/themes/education.aspx }\end{array}$ \\
\hline & $\begin{array}{l}\text { IRIS: A digital depository of instruments and materials for research into } \\
\text { second languages. } \\
\text { https://www.iris-database.org }\end{array}$ \\
\hline \multirow[t]{2}{*}{ Open Outputs } & $\begin{array}{l}\text { Open access journals. } \\
\text { https://journals.sfu.ca/fIr/index.php/journal } \\
\text { https://journals.sub.uni-hamburg.de/hup2/ijrvet/index } \\
\text { https://www.journals.elsevier.com/international-journal-of-educational- } \\
\text { research-open } \\
\text { https://journals.sagepub.com/home/ero }\end{array}$ \\
\hline & $\begin{array}{l}\text { Open education science preprint repository. } \\
\text { https://edarxiv.org/ }\end{array}$ \\
\hline
\end{tabular}

\section{Library and Information Science (including Open Education)}

\section{Examples of open research practices}

Open Outputs: "Evergreen ILS (https://evergreen-ils.org/) is an open source and free library management software which offers public catalogue interface along with features that help users with the back-end workflow operations." It allows finding library materials, and helps libraries manage, catalogue, and circulate those materials as well as providing multiple payment options with self-registration and self-checkouts options. It is used by nearly two thousand libraries around the world and is suited for all sizes of libraries from small to large complex library set ups.

Table of resources

\begin{tabular}{|c|c|}
\hline $\begin{array}{l}\text { Transparency } \\
\text { Category }\end{array}$ & Resources \\
\hline \multirow[t]{2}{*}{ General } & $\begin{array}{l}\text { Chen, M. and Du, Y. (2016). The status of open access library and } \\
\text { information science journals in SSCI. The Electronic Library, 34(5), 722- } \\
\text { 739. } \\
\text { https://doi.org/10.1108/EL-05-2015-0070 }\end{array}$ \\
\hline & $\begin{array}{l}\text { Chilimo, W. L., and Onyancha, O. B. (2018). How open is open access } \\
\text { research in Library and Information Science?. South African Journal of } \\
\text { Libraries and Information Science, 84(1), 11-19. }\end{array}$ \\
\hline
\end{tabular}




\begin{tabular}{|c|c|}
\hline & https://doi.org/10.7553/84-1-1710 \\
\hline & $\begin{array}{l}\text { Passenger Pigeon Manifesto "A call to public galleries, libraries, } \\
\text { archives, museums, and their funders to liberate our cultural heritage } \\
\text { that has already been digitised." } \\
\text { https://ppmanifesto.hcommons.org/ }\end{array}$ \\
\hline & $\begin{array}{l}\text { Intro to open educational resources. } \\
\text { https://rmit.libguides.com/openeducationalresources }\end{array}$ \\
\hline & $\begin{array}{l}\text { What is Open Education. } \\
\text { https://ec.europa.eu/jrc/en/open-education } \\
\text { https://open.ed.ac.uk/what-is-open-education-practice/ }\end{array}$ \\
\hline & $\begin{array}{l}\text { Coughlan, T. (2020). The use of open data as a material for learning. } \\
\text { Educational Technology Research and Development, 68(1), 383-411. } \\
\text { Doi: } \underline{10.1007 / s 11423-019-09706-y}\end{array}$ \\
\hline & $\begin{array}{l}\text { Blog on switching to open educational resources. } \\
\text { https://www.edutopia.org/blog/transitioning-to-open-educational- } \\
\underline{\text { resources-andrew-marcinek }}\end{array}$ \\
\hline & $\begin{array}{l}\text { Santos-Hermosa, G., \& Atenas, J. (2022). Building Capacities in Open } \\
\text { Knowledge: Recommendations for Library and Information Science } \\
\text { Professionals and Schools. Frontiers In Education, } 7 . \\
\text { https://doi.org/10.3389/feduc.2022.866049 }\end{array}$ \\
\hline Open Methods & $\begin{array}{l}\text { Research methods in LIS open access textbook chapter. } \\
\text { https://www.intechopen.com/books/qualitative-versus-quantitative- } \\
\underline{\text { research/research-methods-in-library-and-information-science }}\end{array}$ \\
\hline \multirow[t]{3}{*}{ Open Data } & $\begin{array}{l}\text { List of key databases. } \\
\text { https://libguides.usc.edu/libsci/databases }\end{array}$ \\
\hline & $\begin{array}{l}\text { Open access journals. } \\
\text { https://journals.library.uallberta.ca/eblip/index.php/EBLIP/index } \\
\text { http://www.inthelibrarywiththeleadpipe.org/ }\end{array}$ \\
\hline & $\begin{array}{l}\text { How to use open data. } \\
\text { https://www.fosteropenscience.eu/learning/use-open-data-in- } \\
\text { teaching/\#/id/5b06ca3ba8216e322da360b6 }\end{array}$ \\
\hline \multirow[t]{2}{*}{ Open Outputs } & $\begin{array}{l}\text { Preprint repository. } \\
\text { http://eprints.rclis.org/ }\end{array}$ \\
\hline & $\begin{array}{l}\text { Preprint repository. } \\
\text { https://osf.io/preprints/lissa }\end{array}$ \\
\hline
\end{tabular}




\begin{tabular}{|l|l|}
\hline & $\begin{array}{l}\text { Open Access Resources explained. } \\
\text { https://salve.libguides.com/OER/OAT }\end{array}$ \\
\cline { 2 - 3 } & $\begin{array}{l}\text { List of open access resources. } \\
\text { Multidisciplinary Resources - K-12 Open Education Resources (OER) - } \\
\text { LibGuides at Appalachian State University (appstate.edu) }\end{array}$ \\
\hline
\end{tabular}

\section{Law}

\section{Examples of open research practices}

Open Outputs: "Laws (ISSN 2075-471X) is an international, peer-reviewed, quick-refereeing scholarly open access journal (free for readers), which publishes works from extensive fields including legal systems, legal theory, legal institutions, and a broad range of legal subjects. To guarantee a rapid refereeing and editorial process, Laws follows standard publication practices in the natural sciences." https://www.moli.com/journal/laws

Table of resources

\begin{tabular}{|l|l|}
\hline $\begin{array}{l}\text { Transparency } \\
\text { category }\end{array}$ & Resources \\
\hline General & $\begin{array}{l}\text { Guide on accessing open legal resources - includes lists of books, } \\
\text { journals and repository sites. } \\
\text { https://libguides.ials.sas.ac.uk/openfreeresources }\end{array}$ \\
\hline Open Methods & $\begin{array}{l}\text { Journal article on the surge of open research in law and its benefits. } \\
\text { https://www.bjutijdschriften.nl/tijdschrift/lawandmethod/2016/04/lawandm }\end{array}$ \\
\hline Open Data & $\begin{array}{l}\text { Journal of Open Access to Law. } \\
\text { https://ojs.law.cornell.edu/index.php/joal/index }\end{array}$ \\
\cline { 2 - 3 } & $\begin{array}{l}\text { Open access case databases. } \\
\text { https://www.bailii.org/ }\end{array}$ \\
\hline $\begin{array}{l}\text { https://www.legislation.gov.uk/ } \\
\text { Open Outputs }\end{array}$ & $\begin{array}{l}\text { Preprint repository. } \\
\text { https://osf.io/preprints/lawarxiv } \\
\text { https://law.bepress.com/ }\end{array}$ \\
\hline
\end{tabular}

\section{Leisure/Hospitality and Tourism}

\section{Examples of open research practices}

Open Methods: MethodsX is an open-access journal where methods used in research studies can be regularly updated by authors and viewed by readers in order to gain precise insight into the methods used and how they could be replicated. An example of its usage is Jillian Student and colleagues' recent paper which explored the factors affecting coastal tourism using an agent-based modelling approach featuring human-environmental interactions. Specifics of the model can be accessed and viewed on MethodsX. 
(Student, J., Kramer, M. R., and Steinmann, P. (2020). Simulating emerging coastal tourism vulnerabilities: an agent-based modelling approach. Annals of Tourism Research, 85. https://doi.org/10.1016/j.annals.2020.103034)

\section{Table of resources}

\begin{tabular}{|c|c|}
\hline $\begin{array}{l}\text { Transparency } \\
\text { category }\end{array}$ & Resources \\
\hline \multirow[t]{2}{*}{ General } & $\begin{array}{l}\text { Brunner-Sperdin, A. and Peters, M. (2005). Importance and } \\
\text { Measurement of Entrepreneurial Quality and Processes in } \\
\text { Tourism. Journal of Quality Assurance in Hospitality and } \\
\text { Tourism, 5(1), 73-90. } \\
\text { https://doi.org/10.1300/J162v05n01 } 06\end{array}$ \\
\hline & $\begin{array}{l}\text { Summary of Core Research Resources for Hospitality and Tourism } \\
\text { (Including Journals and Data Sets) } \\
\text { https://guides.nyu.edu/Hospitality/home }\end{array}$ \\
\hline Open Methods & $\begin{array}{l}\text { Resources required - please complete the Google form (link provided in } \\
\text { the introduction) if you can input here. }\end{array}$ \\
\hline Open Data & $\begin{array}{l}\text { Ardito, L., Cerchione, R., Del Vecchio, P. and Raguseo, E. (2019). Big } \\
\text { data in smart tourism: challenges, issues and opportunities. Current } \\
\text { Issues in Tourism, 22(15), 1805-1809. } \\
\text { https://doi.org/10.1080/13683500.2019.1612860 }\end{array}$ \\
\hline Open Outputs & $\begin{array}{l}\text { Open access journals. } \\
\text { https://www.longdom.org/tourism-hospitality.html } \\
\text { https://www.mdpi.com/journal/tourismhosp } \\
\text { https://www.journals.elsevier.com/journal-of-hospitality-leisure-sport-and- } \\
\text { tourism-education }\end{array}$ \\
\hline $\begin{array}{l}\text { Open } \\
\text { Education }\end{array}$ & $\begin{array}{l}\text { Research methods downloadable textbook. } \\
\text { https://www.academia.edu/36341057/Handbook of Research Methods } \\
\text { for Tourism and Hospitality Management }\end{array}$ \\
\hline
\end{tabular}

\section{Humanities}

\section{Examples of open research practices}

Open Data: The following are examples of things that could be listed as open data: lists, tables or matrices containing organised, numerical, categorical, and ordinal information (e.g. the population of French medieval cities, a list of participants in the Society of Independent Artists exhibition in 1917, the GDP of European countries before and after Brexit, etc.).

(Based on information in: https://repository.dri.ie/catalog/tq582c863)

Open Data: Objects can also be research data. These include historical artefacts, digital (incl. digitised) documents, images, sound and video recordings (e.g. archaeological finds, 
medieval manuscripts, poetry texts, social media posts, paintings, recording of a theatre performance).

(Based on information in: https://repository.dri.ie/catalog/tq582c863)

Open Methods: Make the workflow open of how you arrived at your open data from your source. Share or at least indicate, to the greatest extent that you can, the contextual components and contributors to your understanding of the material and realization of your conclusions etc.

(Based on information in: https://zenodo.org/record/2657248\#.Xvxm1yhKhaS)

Open Methods and Open Outputs: Establish your sharing rights while you are at the archive, or otherwise accessing sources. Have the documents I need been digitised? If so, how can I obtain digital copies? If not, may I photograph documents myself or order photographs? May I share any photographs I take away? Under what conditions? Under what license(s) (such as the Creative Commons CC-BY)?

(Based on information in: https://zenodo.org/record/2657248\#.Xvxm1yhKhaS)

Table of resources

\begin{tabular}{|c|c|}
\hline $\begin{array}{l}\text { Transparency } \\
\text { category }\end{array}$ & Resources \\
\hline \multirow[t]{3}{*}{ General } & $\begin{array}{l}\text { The Digital Research Infrastructure for the Arts and Humanities } \\
\text { (DARIAH) aims to enhance and support digitally enabled research and } \\
\text { teaching across the arts and humanities. } \\
\text { https://www.dariah.eu/activities/open-science/dariah-open/ }\end{array}$ \\
\hline & $\begin{array}{l}\text { Digital Preservation for the Arts, Social Sciences and Humanities } \\
\text { biennial conference. } \\
\text { http://dpassh.org/ }\end{array}$ \\
\hline & $\begin{array}{l}\text { Research results, data, scientific publications and projects related to the } \\
\text { domain of Digital Humanities. This includes Humanities, Cultural } \\
\text { Heritage, History, Archaeology and related fields. Includes the following } \\
\text { tabs of sharable resources: publications, research data, software, other } \\
\text { research. } \\
\text { https://dh-ch.openaire.eu/ }\end{array}$ \\
\hline Open Methods & $\begin{array}{l}\text { Edmond and Tóth-Czifra (2018). Open Data for Humanists, A Pragmatic } \\
\text { Guide. Zenodo. } \\
\text { http://doi.org/10.5281/zenodo.2657248 }\end{array}$ \\
\hline \multirow[t]{2}{*}{ Open Data } & $\begin{array}{l}\text { A guide to data management in the humanities. } \\
\text { https://allea.org/portfolio-item/sustainable-and-fair-data-sharing-in-the- } \\
\text { humanities/ }\end{array}$ \\
\hline & $\begin{array}{l}\text { DARIAH Research Data Management Working Group. } \\
\text { https://www.dariah.eu/activities/working-groups/research-data- } \\
\text { management/ }\end{array}$ \\
\hline
\end{tabular}




\begin{tabular}{|l|l|}
\hline \multirow{5}{*}{ Open Outputs } & $\begin{array}{l}\text { Reference library for data management in humanities. } \\
\text { https://www.zotero.org/groups/2427138/data management best practic } \\
\text { es in the humanities/library }\end{array}$ \\
\cline { 2 - 3 } & $\begin{array}{l}\text { Blog on Data Sharing in the Humanities } \\
\text { Data sharing in the humanities: translating policies into practice } \\
\text { (f1000.com) }\end{array}$ \\
\hline $\begin{array}{l}\text { SAGE Advance (multidisciplinary Humanities and Social Sciences } \\
\text { preprint community). } \\
\text { https://advance.sagepub.com/ }\end{array}$ \\
\cline { 2 - 3 } & $\begin{array}{l}\text { Open Access Journals } \\
\text { https://www.mdpi.com/journal/humanities } \\
\text { https://www.openlibhums.org/journals/ }\end{array}$ \\
\cline { 2 - 2 } & $\begin{array}{l}\text { Repository. } \\
\text { https://osf.io/preprints/socarxiv }\end{array}$ \\
\hline
\end{tabular}

\section{History}

Examples of open research practices

Open Methods: The Institute of Historical Research (IHR) has continuously played a vital role in ensuring open access of history publications with three of their book series having recently gained open access. Meanwhile, they raise awareness on open research by educating current historians via workshops, thus creating discussion opportunities.

(https://www.history.ac.uk/publications/open-access)

Table of resources

\begin{tabular}{|l|l|}
\hline $\begin{array}{l}\text { Transparency } \\
\text { category }\end{array}$ & Resources \\
\hline General & $\begin{array}{l}\text { IHR's open access policy and aims. } \\
\text { https://www.history.ac.uk/publications/open-access }\end{array}$ \\
\cline { 2 - 3 } & $\begin{array}{l}\text { The Programming Historian. } \\
\text { https://programminghistorian.org/ }\end{array}$ \\
\hline \multirow{3}{*}{ Open Methods } & $\begin{array}{l}\text { IHR's list of open access resources. } \\
\text { https://www.history.ac.uk/library/collections/online-resources/open- }\end{array}$ \\
$\begin{array}{l}\text { access-resources } \\
\text { Open Data }\end{array}$ & $\begin{array}{l}\text { Archaeology Dataset. } \\
\text { https://openarchaeologydata.metajnl.com/articles/10.5334/joad.57/ }\end{array}$ \\
\cline { 2 - 2 } & $\begin{array}{l}\text { Archaeology Data Service. } \\
\text { https://archaeologydataservice.ac.uk/ }\end{array}$ \\
\hline
\end{tabular}




\begin{tabular}{|l|l|}
\hline \multirow{2}{*}{ Open Outputs } & $\begin{array}{l}\text { Data and Data Sharing } \\
\text { Course: Module 1: Introduction, Topic: About the Tutorial (sas.ac.uk) }\end{array}$ \\
& $\begin{array}{l}\text { Royal Historical Society guide to open access. } \\
\text { https://royalhistsoc.org/early-career-historians/open-access/ }\end{array}$ \\
\cline { 2 - 2 } & $\begin{array}{l}\text { Preprint repository. } \\
\text { https://osf.io/preprints/socarxiv }\end{array}$ \\
\cline { 2 - 2 } & $\begin{array}{l}\text { Open Access Journals } \\
\text { https://www.cambridge.org/core/journals/historical-journal/open-access } \\
\text { https://www.journals.uchicago.edu/journals/imh/open }\end{array}$ \\
\hline
\end{tabular}

\section{Archaeology and Classics}

\section{Examples of open research practices}

Open Methods: "One of the most promising vector-based information to be made available on the web is an eXtensible Markup Language (XML)-based solution called Scalable Vector Graphics (SVG). SVG was defined by a working group of the World Wide Web Consortium (W3C) and has subsequently become their official recommendation for representing vector graphics on the Web in XML (Eisenberg 2002, 6; Watt 2002, xviii). Because SVG is an XML application, it is freely available, not dependent on a particular browser or platform, and interoperable with other XML applications. Large-scale plan and section drawings originally created on Permatrace were digitised by Guy Hopkinson for use in the Internet Archaeology publication Excavations at Cricklade, Wiltshire, 1975, by Jeremy Haslam, designed as an exercise in 'retrospective publication', to illustrate how traditional forms of visual recording might be digitised for online publications."

(https://intarch.ac.uk/journal/issue20/wright index.html)

\section{Table of resources}

\begin{tabular}{|c|c|}
\hline $\begin{array}{l}\text { Transparency } \\
\text { category }\end{array}$ & Resources \\
\hline \multirow[t]{4}{*}{ General } & $\begin{array}{l}\text { Marwick. B, et al. (2017). Open Science in Archaeology. SAA } \\
\text { Archaeological Records, 17(4), 8-14. } \\
\text { Doi: } 10.17605 / O S F .10 / 3 D 6 X X\end{array}$ \\
\hline & $\begin{array}{l}\text { Huggett, J. (2017). Reuse remix recycle: repurposing archaeological } \\
\text { digital data. Advances in Archaeological Practice, 6(2), 93-104. } \\
\text { Doi: } \underline{10.1017 / a a p .2018 .1}\end{array}$ \\
\hline & $\begin{array}{l}\text { Karoune and Plomp (2022). Removing Barriers to Reproducible } \\
\text { Research in Archaeology (Version v2). Zenodo. } \\
\text { https://doi.org/10.5281/zenodo.6618672 }\end{array}$ \\
\hline & $\begin{array}{l}\text { Presentation on Registered Reports in Archaeology } \\
\text { OSF }\end{array}$ \\
\hline
\end{tabular}




\begin{tabular}{|c|c|}
\hline \multirow[t]{2}{*}{ Open Methods } & $\begin{array}{l}\text { Papers covering open methods in Archaeology. } \\
\text { https://core.tdar.org/collection/29739/open-methods-in-archaeology-how- } \\
\text { to-encourage-reproducible-research-as-the-default-practice }\end{array}$ \\
\hline & $\begin{array}{l}\text { Open methods and resources. } \\
\text { https://archaeologicalnetworks.wordpress.com/resources/ } \\
\underline{\text { https://library.ics.sas.ac.uk/open-access-resources }}\end{array}$ \\
\hline \multirow[t]{4}{*}{ Open Data } & $\begin{array}{l}\text { Archaeology data service. } \\
\text { https://archaeologydataservice.ac.uk/ }\end{array}$ \\
\hline & $\begin{array}{l}\text { Open access data. } \\
\text { https://opencontext.org/ } \\
\text { https://core.tdar.org/ } \\
\text { https://homer.library.northwestern.edu/splash.html }\end{array}$ \\
\hline & $\begin{array}{l}\text { Open software. } \\
\text { https://github.com/benmarwick/ctv-archaeology } \\
\underline{\text { https://open-archaeo.info/ }}\end{array}$ \\
\hline & $\begin{array}{l}\text { Marwick, B., \& Birch, S. (2018). A Standard for the Scholarly Citation of } \\
\text { Archaeological Data as an Incentive to Data Sharing. Advances in } \\
\text { Archaeological Practice, 6(2), 125-143. } \\
\text { doi:10.1017/aap.2018.3 }\end{array}$ \\
\hline \multirow[t]{2}{*}{ Open Outputs } & $\begin{array}{l}\text { Preprint repository. } \\
\text { https://osf.io/preprints/socarxiv/discover } \\
\text { https://isoarch.eu/ } \\
\text { https://archaeo.peercommunityin.org/ }\end{array}$ \\
\hline & $\begin{array}{l}\text { Open Access journal/data/catalogue. } \\
\text { https://intarch.ac.uk/ } \\
\text { https://openarchaeologydata.metajnl.com// } \\
\text { https://www.degruyter.com/view/journals/ } \\
\text { https://spotlight.vatlib.it/ } \\
\text { https://aeschylus-agamemnon.fileli.unipi.it/ } \\
\text { https://www.hcsjournal.org/ojs/index.php/hcs } \\
\text { https://propylaeum.de/home } \\
\text { https://academic.oup.com/bics/issue }\end{array}$ \\
\hline
\end{tabular}

\section{Philosophy, Theology and Religious Studies}

\section{Examples of open research practices}

Open Data: Open text and open images. For example, "Hume Texts Online is a free and open access collection of works...[which] includes every philosophical text that Hume published, in accurate editions that faithfully represent the original 18th century publications, but without neglecting the advantages of modern online texts...Thanks to the National Library of Scotland and the Royal Society of Edinburgh, we are also able to reproduce here high-quality digital images of Hume's manuscript of the Dialogues concerning Natural Religion. These 
pages are made available alongside the text of the first posthumous 1779 edition." (https://davidhume.org/)

Table of resources

\begin{tabular}{|c|c|}
\hline $\begin{array}{l}\text { Transparency } \\
\text { category }\end{array}$ & Resources \\
\hline General & $\begin{array}{l}\text { Open Access Resources in Religious and Theological Studies: Getting } \\
\text { Started. } \\
\text { https://guides.library.duke.edu/openreligion }\end{array}$ \\
\hline \multirow[t]{2}{*}{ Open Methods } & $\begin{array}{l}\text { Detailed overview of current progress towards open access literature. } \\
\text { open-access.network: Open Access in Philosophy }\end{array}$ \\
\hline & $\begin{array}{l}\text { Open Communication Science: A primer on why and some } \\
\text { recommendations for how. } \\
\text { https://mediarxiv.org/6bxyz/ }\end{array}$ \\
\hline \multirow[t]{2}{*}{ Open Data } & $\begin{array}{l}\text { Hume texts online. } \\
\text { https://davidhume.org/ }\end{array}$ \\
\hline & $\begin{array}{l}\text { Archive data. } \\
\text { https://thearda.com/ }\end{array}$ \\
\hline \multirow[t]{7}{*}{ Open Outputs } & $\begin{array}{l}\text { List of open access journals. } \\
\text { https://libguides.du.edu/c.php?g=131579\&p=2774089 } \\
\underline{\text { https://www.degruyter.com/view/journals/opth/opth-overview.xml }}\end{array}$ \\
\hline & $\begin{array}{l}\text { Open access guide. } \\
\text { https://umb.libguides.com/c.php?g=350815\&p=2468261 }\end{array}$ \\
\hline & $\begin{array}{l}\text { Open access resources on the Muslim world. } \\
\text { https://archnet.org/ }\end{array}$ \\
\hline & $\begin{array}{l}\text { List of open access resources and digital library. } \\
\text { https://library.ucalgary.ca/religiousstudieswebguide/journals } \\
\text { https://dialnet.unirioja.es/documentos } \\
\text { http://oadtl.org/open-access-journals }\end{array}$ \\
\hline & $\begin{array}{l}\text { Theological studies journal search. } \\
\text { https://cse.google.com/cse?cx=018443097211386924752:Iuwi5uy2abe }\end{array}$ \\
\hline & $\begin{array}{l}\text { Preprint repository. } \\
\text { http://philsci-archive.pitt.edu/ }\end{array}$ \\
\hline & $\begin{array}{l}\text { Open access archive. } \\
\text { https://philpapers.org/ }\end{array}$ \\
\hline
\end{tabular}




\section{Modern Language, Literature and Linguistics}

\section{Examples of open research practices}

Open Methods: Language and Cognition field manuals and stimulus materials from the Max Planck Institute for Psycholinguistics (http://fieldmanuals.mpi.nl/) provide an example of open resources and historical data for the fields of elicitation of semantics and collection of verbal behaviour. Due to the open nature of the tasks, they have been refined over many uses, which makes them a "joint product of many scholars working in over 50 languages and cultures." The use of these materials can be coupled with open data from earlier uses, for comparison.

Open Data: The Arts and Humanities Research Council (AHRC) requires the production of a technical plan for any project it funds in which digital technologies play a significant part. Asa case study of this, Francesca Benatti worked on a project creating a searchable database, curated mostly from existing resources. She was required to produce a technical plan for the project, outlining the methodology, any technical support needed, the planned outputs, and a plan for the preservation, sustainability and future use of the project.

(See https://www.dcc.ac.uk/resources/developing-rdm-services/dmps-arts-and-humanities)

Table of resources

\begin{tabular}{|l|l|}
\hline $\begin{array}{l}\text { Transparency } \\
\text { category }\end{array}$ & Resources \\
\hline General & $\begin{array}{l}\text { Guide on transitioning to open access. } \\
\text { https://www.lingoa.eu/about/mission/ }\end{array}$ \\
\cline { 2 - 3 } & $\begin{array}{l}\text { A collection of instruments, materials, stimuli, and data coding and } \\
\text { analysis tools used for research into second languages. } \\
\text { https://www.iris-database.org/iris/app/home/index }\end{array}$ \\
\cline { 2 - 3 } & $\begin{array}{l}\text { Encyclopaedia of linguistics. } \\
\text { http://www.glottopedia.org/index.php/Main Page }\end{array}$ \\
\cline { 2 - 3 } & $\begin{array}{l}\text { Marsden, E., Morgan-Short, K., Trofimovich, P., \& Ellis, N. C. (2018). } \\
\text { Introducing registered reports at language learning: Promoting } \\
\text { transparency, replication, and a synthetic ethic in the language sciences. } \\
\text { Language Learning, 68(2), 309-320. } \\
\text { https://onlinelibrary.wiley.com/doi/full/10.1111/lang.12284 }\end{array}$ \\
\cline { 2 - 3 } & $\begin{array}{l}\text { Marsden, E., Crossley, S., Ellis, N., Kormos, J., Morgan-Short, K., \& } \\
\text { Thierry, G. (2019). Inclusion of research materials when submitting an } \\
\text { article to language learning. Language Learning, 69(4), 795-801. } \\
\text { https://onlinelibrary.wiley.com/doi/full/10.1111/lang.12378 }\end{array}$ \\
\cline { 2 - 2 } & $\begin{array}{l}\text { AHRC's open access policy rationale } \\
\text { Open access policy update: July 2022 - UKRI }\end{array}$ \\
\hline Open Methods & $\begin{array}{l}\text { Paper outlining how methods can be made more open to the public. } \\
\text { https://doi.org/10.1111/lang.12337 }\end{array}$ \\
\hline
\end{tabular}




\begin{tabular}{|c|c|}
\hline & $\begin{array}{l}\text { Sharing linguistic questionnaires and elicitation stimuli. } \\
\text { http://tulquest.huma-num.fr/ }\end{array}$ \\
\hline & $\begin{array}{l}\text { Language and Cognition field manuals and stimulus materials. } \\
\text { http://fieldmanuals.mpi.nl/ }\end{array}$ \\
\hline & $\begin{array}{l}\text { Tools for analysing language corpora. } \\
\text { http://corpora.lancs.ac.uk/lancsbox/ }\end{array}$ \\
\hline & $\begin{array}{l}\text { Tools for analysing corpus linguistic data. } \\
\text { https://www.laurenceanthony. net/software/antconc/ }\end{array}$ \\
\hline & $\begin{array}{l}\text { Website for statistical analysis. } \\
\text { http://langtest.jp/ }\end{array}$ \\
\hline Open Data & $\begin{array}{l}\text { List of data repositories. } \\
\text { https://guides.lib.ku.edu/c.php?g=94923\&p=1224538 }\end{array}$ \\
\hline & $\begin{array}{l}\text { Child Language Data Exchange System. } \\
\text { https://childes.talkbank.org/ }\end{array}$ \\
\hline & $\begin{array}{l}\text { Open data texts. } \\
\text { https://www.english-corpora.org/ }\end{array}$ \\
\hline & $\begin{array}{l}\text { British Library Digital Collections and Data } \\
\text { https://data.bl.uk/ }\end{array}$ \\
\hline & $\begin{array}{l}\text { Collection of Datasets for Natural Language Processing } \\
\text { https://medium.com/@ODSC/20-open-datasets-for-natural-language- } \\
\text { processing-538fbfaf8e38 }\end{array}$ \\
\hline Open Outputs & $\begin{array}{l}\text { List of open access resources for modern languages. } \\
\text { https://modernlanguages.sas.ac.uk/about-us/online-resources/open- } \\
\text { access-resources-modern-languages } \\
\text { https://www.modernlanguagesopen.org/ }\end{array}$ \\
\hline & $\begin{array}{l}\text { Guides to open access for linguistics. } \\
\text { http://www.lagb.org.uk/OpenAccess } \\
\text { http://humans-who-read-grammars.blogspot.com/p/open-access- } \\
\text { publishing-in.html } \\
\text { https://ling.auf.net/ }\end{array}$ \\
\hline & $\begin{array}{l}\text { List of platinum open access linguistics journals. } \\
\text { https://oaling.wordpress.com/ }\end{array}$ \\
\hline & $\begin{array}{l}\text { Lists of open access resources for literature } \\
\text { https://libguides.tyndale.ca/c.php?g=315370\&p=2107755 } \\
\text { https://libguides. southernct.edu/c.php?g=721855\&p=5148244 }\end{array}$ \\
\hline
\end{tabular}




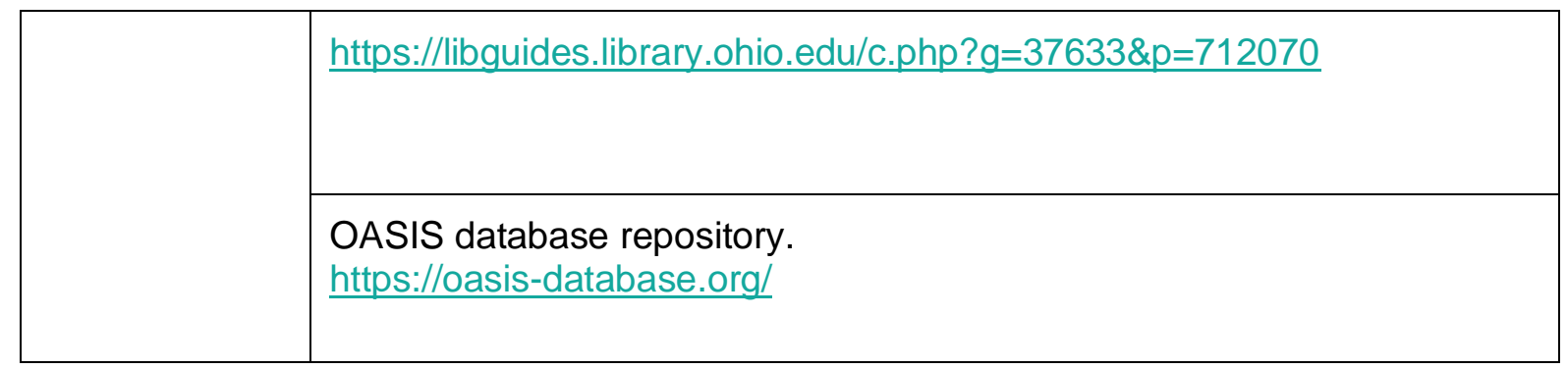

\section{Art and Design}

\section{Examples of open research practices}

Open Outputs: The National Gallery of Art (NGA) is a key example of a gallery that is gradually opening its resources for the public to use freely. This is in the format of an online repository named 'NGA Images' with the following terms: "NGA Images is a repository of digital images of the collections of the National Gallery of Art. On this website you can search, browse, share, and download images. A standards-based reproduction guide and a help section provide advice for both novices and experts. More than 45,000 open access digital images up to 4000 pixels each are available free of charge for download and use. NGA Images is designed to facilitate learning, enrichment, enjoyment, and exploration." As well as providing staff and external users with simplified access to research material, the move to open access has resulted in an increased awareness of the gallery's collections, thus highlighting the advantages of open research.

(https://images.nga.gov/en/page/show home page.html)

\section{Table of resources}

\begin{tabular}{|l|l|}
\hline $\begin{array}{l}\text { Transparency } \\
\text { category }\end{array}$ & Resources \\
\hline General & $\begin{array}{l}\text { Benefits of open access for art and design scholarships. } \\
\text { https://blogs.openbookpublishers.com/the-monograph-crisis-open- } \\
\text { access-for-art-and-design-scholarship/ }\end{array}$ \\
\cline { 2 - 2 } & $\begin{array}{l}\text { Blog post exploring research data in the creative arts. } \\
\text { https://researchdata.jiscinvolve.org/wp/2016/11/22/research-data- } \\
\text { creative-performing-arts/ }\end{array}$ \\
\hline Open Methods & $\begin{array}{l}\text { Boisseau, É., Omhover, J. F., and Bouchard, C. (2018). Open-design: A } \\
\text { state of the art review. Design Science, 4. } \\
\text { https://doi.org/10.1017/dsj.2017.25 }\end{array}$ \\
\cline { 2 - 2 } & $\begin{array}{l}\text { Open-source design publishing software. } \\
\text { https://www.scribus.net }\end{array}$ \\
\hline Open Data & $\begin{array}{l}\text { Resources required - please complete the Google form (link provided in } \\
\text { the introduction) if you can input here. }\end{array}$ \\
\hline
\end{tabular}




\begin{tabular}{|c|c|}
\hline \multirow[t]{4}{*}{ Open Outputs } & $\begin{array}{l}\text { Open access journals. } \\
\text { https://openartsjournal.org } \\
\text { http://www.19thc-artworldwide.org/spring19/ } \\
\text { https://www.intellectbooks.com/artifact-journal-of-design-practice } \\
\text { https://www.jar-online.net }\end{array}$ \\
\hline & $\begin{array}{l}\text { Open art images repository. } \\
\text { https://images.nga.gov/en/page/show home page.html }\end{array}$ \\
\hline & $\begin{array}{l}\text { Open Access University Repositories } \\
\text { https://research.uca.ac.uk/ } \\
\text { http://radar.gsa.ac.uk/ }\end{array}$ \\
\hline & $\begin{array}{l}\text { Visual arts data skills for researchers. } \\
\text { http://www.vads4r.vads.ac.uk/p/online-learning.html }\end{array}$ \\
\hline
\end{tabular}

\section{Music, Drama and Performing Arts, Film and Screen Studies}

\section{Examples of open research practices}

Open Data: "MusicLab is an innovation project by RITMO (http://www.uio.no/ritmo) and the University Library (http://ub.uio.no/). The aim is to explore new methods for conducting research, research communication and education. The project is organized around events: a concert in a public venue, which is also the object of study. The events also contain an edutainment element through panel discussions with world-leading researchers and artists, as well 'data jockeying' in the form of live data analysis of recorded data." This up-and-coming project namely merges the study of music with physiology using various types of technologies measuring bodily responses. All resources (including data findings) are fully free and available to everyone due to the project's aims of exploring Open Science within research and researchbased education.

(https://www.uio.no/ritmo/english/news-and-events/events/musiclab/)

Table of resources

\begin{tabular}{|l|l|}
\hline $\begin{array}{l}\text { Transparency } \\
\text { category }\end{array}$ & Resources \\
\hline General & $\begin{array}{l}\text { Podcast on how music research can be made more open. } \\
\text { https://site.uit.no/ub/2020/01/03/music-research/ }\end{array}$ \\
\hline Open Methods & $\begin{array}{l}\text { Paper on a new open-source application for musical recording analysis. } \\
\text { Cannam, C., Landone, C., and Sandler, M. (2010). Sonic visualiser: an } \\
\text { open-source application for viewing, analysing, and annotating music } \\
\text { audio files. Association for Computing Machinery, 1467-1468. } \\
\text { https://doi.org/10.1145/1873951.1874248 }\end{array}$ \\
\hline Open Data & $\begin{array}{l}\text { Resource facilitating music data reusability. } \\
\text { http://soundsoftware.ac.uk/ }\end{array}$ \\
\hline
\end{tabular}




\begin{tabular}{|l|l|}
\hline Open Outputs & $\begin{array}{l}\text { Open film studies preprint archive. } \\
\text { https://mediarxiv.org }\end{array}$ \\
\cline { 2 - 3 } & $\begin{array}{l}\text { Performing arts journal. } \\
\text { https://cnu.edu/jpalhe/ }\end{array}$ \\
\cline { 2 - 3 } & $\begin{array}{l}\text { Performing arts digital books. } \\
\text { https://www.doabooks.org/doab?func=subject\&cpld=7\&uiLanguage=en }\end{array}$ \\
\cline { 2 - 3 } & $\begin{array}{l}\text { Musical performance journal. } \\
\text { https://scholarship.claremont.edu/ppr/ }\end{array}$ \\
\hline
\end{tabular}

\section{Cultural and Media Studies}

\section{Examples of open research practices}

Open Data: The Database of Places, Language, Culture and Environment (D-PLACE) is an expandable and open-access resource which combines data from over 1400 human societies in terms of their language, culture and environment. Drawing upon the current barrier to fully comprehending cultural diversity due to inaccessible repositories, D-PLACE helps to combat this by providing: "i) location of relevant cultural data, (ii) linking data from distinct sources using diverse ethnonyms, (iii) variable time and place foci for data, and (iv) spatial and historical dependencies among cultural groups that present challenges for analysis." Data is available in an easily downloadable format (e.g., tables, maps and linguistic trees). With the possibility for researchers to utilise large-scale phylogenetic analyses, one key field that can benefit from this is the study of cultural evolution.

(https://doi.org/10.1371/journal.pone.0158391)

Table of resources

\begin{tabular}{|l|l|}
\hline $\begin{array}{l}\text { Transparency } \\
\text { category }\end{array}$ & Resources \\
\hline General & $\begin{array}{l}\text { Overview of progression towards open research. } \\
\text { https://mediastudies.hypotheses.org/867 }\end{array}$ \\
\cline { 2 - 2 } & $\begin{array}{l}\text { Introduction to Open Science/Research for communication scholars. } \\
\text { https://doi.org/10.1093/joc/jaz052 } \\
\text { https://doi.org/10.1080/19312458.2019.1685660 }\end{array}$ \\
\cline { 2 - 2 } & $\begin{array}{l}\text { Presentations about Open Communication regarding research papers, } \\
\text { roundtables and workshops. } \\
\text { https://www.youtube.com/channel/UCLfQ- }\end{array}$ \\
\hline $\begin{array}{l}\text { LCjJMfiFCOEG7e6hkA/playlists } \\
\text { Open Methods }\end{array}$ & $\begin{array}{l}\text { Resources required - please complete the Google form (link provided in } \\
\text { the introduction) if you can input here. }\end{array}$ \\
\hline
\end{tabular}




\begin{tabular}{|c|c|}
\hline Open Data & $\begin{array}{l}\text { Open database on human culture practices. } \\
\text { https://d-place.org/contributions }\end{array}$ \\
\hline \multirow[t]{3}{*}{ Open Outputs } & $\begin{array}{l}\text { Open access repositories/archives. } \\
\text { https://mediarep.org/handle/doc/15273 } \\
\text { https://sciendo.com/journal/TJCP }\end{array}$ \\
\hline & $\begin{array}{l}\text { Open access journals. } \\
\text { https://oamediastudies.com/publish/journals/ } \\
\text { https://journal.media-culture.org.au/index.php/mcjournal } \\
\text { https://journals.dartmouth.edu/cgi- } \\
\text { bin/WebObjects/Journals.woa/xmlpage/4/issue } \\
\text { http://www.transformationsjournal.org } \\
\text { https://csalateral.org/archive/https://csalateral.org/archive/ } \\
\text { https://www.degruyter.com/view/journals/culture/culture-overview.xml }\end{array}$ \\
\hline & $\begin{array}{l}\text { Preprint repository. } \\
\text { https://mediarxiv.org }\end{array}$ \\
\hline
\end{tabular}

\section{Engineering and Technology}

\section{Engineering (including Electrical, Civil, Environmental, Chemical and Mechanical Engineering)}

\section{Examples of open research practices}

Open Data: "Nikola Vasiljević works with unique measurement data of the wind field behind wind turbines, or wake. Having FAIR (Findable, Accessible, Interoperable, Reusable) data is essential to his field, because this kind of data has a high potential to be reused for many decades, from the very first day they are created."

(From https://howtofair.dk/how-to-fair/\#engineering)

Table of resources

\begin{tabular}{|l|l|}
\hline $\begin{array}{l}\text { Transparency } \\
\text { category }\end{array}$ & Resources \\
\hline General & $\begin{array}{l}\text { Munafò, M., Noble, S., Browne, W. et al. Scientific rigor and the art of } \\
\text { motorcycle maintenance. Nat Biotechno/ 32, 871-873 (2014). } \\
\text { https://doi.org/10.1038/nbt.3004 }\end{array}$ \\
\cline { 2 - 3 } & $\begin{array}{l}\text { Detection and Classification of Acoustic Scenes and Events. Community } \\
\text { dashboard of workshops, news and challenges. } \\
\text { Includes blog about change in practice (civil/environmental). } \\
\text { http://dcase.community/ }\end{array}$ \\
\cline { 2 - 3 } & $\begin{array}{l}\text { Manifesto about sharing data (electrical/electronic). } \\
\text { https://theodi.org/article/engineering-data-for-the-public-good-a- }\end{array}$ \\
\hline \begin{tabular}{l} 
manifesto/\#1570462630418-fc70c0a6-7ac3 \\
\hline
\end{tabular}
\end{tabular}




\begin{tabular}{|c|c|}
\hline Open Methods & $\begin{array}{l}\text { Resource guiding researchers on relevant computer skills via regular } \\
\text { workshops. } \\
\text { https://software-carpentry.org }\end{array}$ \\
\hline \multirow[t]{7}{*}{ Open Data } & $\begin{array}{l}\text { The SoundSoftware project provides facilities, training, tools and } \\
\text { incentives to improve the publication and reuse of scientific software and } \\
\text { data in the UK audio and music research community. } \\
\text { http://soundsoftware.ac.uk/ }\end{array}$ \\
\hline & $\begin{array}{l}\text { Institution of Engineering and Technology's (IET) prospective move to } \\
\text { open access. } \\
\text { Transforming our Journals business (theiet.org) }\end{array}$ \\
\hline & $\begin{array}{l}\text { The Software Sustainability Institute facilitates progression towards more } \\
\text { sustainable research software. } \\
\text { https://www.software.ac.uk/about }\end{array}$ \\
\hline & $\begin{array}{l}\text { Open hardware repository. } \\
\text { https://ohwr.org/welcome }\end{array}$ \\
\hline & $\begin{array}{l}\text { Open access tools for data analysis. } \\
\text { https://opensource.com/ }\end{array}$ \\
\hline & $\begin{array}{l}\text { Open-source micro-controller (electrical/electronic). } \\
\text { https://www.arduino.cc }\end{array}$ \\
\hline & $\begin{array}{l}\text { Open data repository. } \\
\text { https://data.4tu.nl/info/en/ }\end{array}$ \\
\hline \multirow[t]{4}{*}{ Open Outputs } & $\begin{array}{l}\text { Open-source 3D printing toolbox data (mechanical). } \\
\text { https://slic3r.org }\end{array}$ \\
\hline & $\begin{array}{l}\text { Open electronics supports development, hacking and playing with } \\
\text { electronics: they share open projects and create products. } \\
\text { https://www.open-electronics.org/about/ }\end{array}$ \\
\hline & $\begin{array}{l}\text { The Open-Source Hardware Association (OSHWA) aims to foster } \\
\text { technological knowledge and encourage research that is accessible, } \\
\text { collaborative and respects user freedom. Hosts annual Open Hardware } \\
\text { Summit and maintains Open-Source Hardware certification. } \\
\text { https://www.oshwa.org/ }\end{array}$ \\
\hline & $\begin{array}{l}\text { Guidelines on creating open hardware. } \\
\text { https://opensource.com/article/18/2/5-steps-creating-successful-open- } \\
\text { hardware }\end{array}$ \\
\hline
\end{tabular}




\begin{tabular}{|c|c|}
\hline & $\begin{array}{l}\text { Pearce, J. M. (2015) Quantifying the Value of Open-Source Hardware } \\
\text { Development. Modern Economy, 6, 1-11. } \\
\text { https://doi.org/10.4236/me.2015.61001 }\end{array}$ \\
\hline & $\begin{array}{l}\text { Open access journals (civil/environmental). } \\
\text { https://opencivilengineeringjournal.com// } \\
\text { https://openbioresources.metajnl.com } \\
\text { https://www.degruyter.com/view/journals/eng/eng-overview.xml }\end{array}$ \\
\hline & $\begin{array}{l}\text { Open access journals (mechanical). } \\
\text { International Journal of Innovative Research in Science, Engineer } \\
\text { (rroij.com) } \\
\text { https://www.omicsonline.org/architectural-engineering-technology.php }\end{array}$ \\
\hline & $\begin{array}{l}\text { Open access journals (chemical). } \\
\text { International Journal of Innovative Research in Science, Engineer } \\
\text { (rroij.com) } \\
\text { https://www.omicsonline.org/analytical-bioanalytical-techniques.php }\end{array}$ \\
\hline & $\begin{array}{l}\text { Open-source software for engineering and other sciences. } \\
\text { https://openfoam.com/ }\end{array}$ \\
\hline & $\begin{array}{l}\text { Preprint repository. } \\
\text { https://engrxiv.org/ }\end{array}$ \\
\hline $\begin{array}{l}\text { Open } \\
\text { Education }\end{array}$ & $\begin{array}{l}\text { Database of open access engineering books, magazines, journals and } \\
\text { conferences. } \\
\text { https://ieeexplore.ieee.org/Xplore/home.jsp }\end{array}$ \\
\hline
\end{tabular}

\section{Architecture, Built Environment and Planning}

\section{Examples of open research practices}

Open Methods: "The OS (OpenStructures) project (http://www.openstructures.net/) explores the possibility of a modular construction model where everyone designs for everyone on the basis of one shared geometrical grid. It initiates a kind of collaborative MECCANOC to which everyone can contribute parts, components and structures." Described as a "threedimensional open-source code from our built environment", this ecosystem explores the idea of designing hardware in the way we design software by having different individuals contribute to one main model as opposed to working on separate entities. This concept has been applied to developing societies within Katanga, Congo in the form of humanitarian architecture by recycling, upcycling and reusing goods as a way of strengthening the local economy. (http://studies.bc-as.org/case-study-1-katanga-congo)

Table of resources

\begin{tabular}{|l|l|}
\hline $\begin{array}{l}\text { Transparency } \\
\text { category }\end{array}$ & Resources \\
\hline General & $\begin{array}{l}\text { Resources required - please complete the Google form (link provided in } \\
\text { the introduction) if you can input here. }\end{array}$ \\
\hline
\end{tabular}




\begin{tabular}{|c|c|}
\hline Open Methods & $\begin{array}{l}\text { Open modular construction system. } \\
\text { https://www.openstructures. net }\end{array}$ \\
\hline Open Data & $\begin{array}{l}\text { Image library resource for architecture projects. } \\
\text { https://www.architecture.com/image-library/ }\end{array}$ \\
\hline \multirow[t]{3}{*}{ Open Outputs } & $\begin{array}{l}\text { List of open access resources. } \\
\text { https://guides.library.upenn.edu/architecture/openaccess }\end{array}$ \\
\hline & $\begin{array}{l}\text { Open access journals. } \\
\text { https://journal.eahn.org } \\
\text { https://www.sciencedirect.com/journal/frontiers-of-architectural-research } \\
\text { https://built-heritage.springeropen.com } \\
\text { https://www.buildingsandcities.org } \\
\text { https://journals.open.tudelft.nl/abe }\end{array}$ \\
\hline & $\begin{array}{l}\text { Open access intellectual resource on Muslim architecture. } \\
\text { https://archnet.org }\end{array}$ \\
\hline
\end{tabular}

\section{Computer Science}

\section{Examples of open research practices}

Open Methods: The Open Science Grid (OSG) is a large-scale computational infrastructure based in the United States and partly funded by the Department of Energy. Having been applied to highly reputable experiments such as the Large Hadron Collider, the OSG holds an invaluable role in supporting a variety of scientific applications by providing service and support to resource providers and research institutions. This is achieved by allowing contributors to grant access to their computing, storage and software resources which promotes usage of shared data and resources. With aims to expand further globally, the OSG plays a key role in ensuring a collaborative environment for scientists and researchers working on computing issues and solutions development as well as guiding new, less experienced users in the computing community. (https://opensciencegrid.org)

Open Methods: Good computing workflow practices. Summarised in Box 1 of Wilson et al. (2017). For example:

"Software

a. Place a brief explanatory comment at the start of every program.

b. Decompose programs into functions.

c. Be ruthless about eliminating duplication.

d. Always search for well-maintained software libraries that do what you need.

e. Test libraries before relying on them.

f. Give functions and variables meaningful names.

g. Make dependencies and requirements explicit.

h. Do not comment and uncomment sections of code to control a program's behaviour.

i. Provide a simple example or test data set.

j. Submit code to a reputable DOI-issuing repository."

Open Data and Open Education: Tim Coughlan from The Open University provides his case study of postgraduate computer science in using open data as a material for describing the process of producing assignments, and learner responses to them. He views open data as a powerful material for designing learning activities because of its qualities of ease of access 
and authenticity. As assignments, students used e-book text files which required them to build an e-reader application. They were then given a set of requirements that progressed from the basic creation of the application, towards challenging them to make use of the data that is available that suits them in complex ways. Feedback from the assignments shows that students responded well to the assignments and reported a high degree of satisfaction. (http://education.okfn.org/handbooks/open-data-as-open-educational-resources/)

\section{Table of resources}

\begin{tabular}{|c|c|}
\hline $\begin{array}{l}\text { Transparency } \\
\text { category }\end{array}$ & Resources \\
\hline \multirow[t]{2}{*}{ General } & $\begin{array}{l}\text { Fernández, D. M., Graziotin, D., Wagner, S., and Seibold, H. (2019). } \\
\text { Open science in software engineering. } \\
\text { https://arxiv.org/abs/1904.06499 }\end{array}$ \\
\hline & $\begin{array}{l}\text { Wilson G, Bryan J, Cranston K, Kitzes J, Nederbragt L, Teal TK (2017) } \\
\text { Good enough practices in scientific } \\
\text { computing. PLoS Comput Biol, 13(6): e1005510. } \\
\text { https://doi.org/10.1371/journal.pcbi.1005510 }\end{array}$ \\
\hline Open Methods & $\begin{array}{l}\text { List of open-source software. } \\
\text { http://openscience.org/software/computer-science/ }\end{array}$ \\
\hline \multirow[t]{3}{*}{ Open Data } & $\begin{array}{l}\text { Datasets. } \\
\text { https://researchportal.hw.ac.uk/en/organisations/computer- } \\
\underline{\text { science/datasets/ }}\end{array}$ \\
\hline & $\begin{array}{l}\text { Open dataset and tools. } \\
\text { https://cocodataset.org/\#home }\end{array}$ \\
\hline & $\begin{array}{l}\text { Open Evidence bank. } \\
\text { https://www.software.ac.uk/open-evidence-bank }\end{array}$ \\
\hline \multirow[t]{4}{*}{ Open Outputs } & $\begin{array}{l}\text { Electronic Colloquium on Computational Complexity. } \\
\text { https://eccc.weizmann.ac.il/eccc/ }\end{array}$ \\
\hline & $\begin{array}{l}\text { Preprint repository. } \\
\text { https://arxiv.org/ }\end{array}$ \\
\hline & $\begin{array}{l}\text { Database of open access conference processing, journals and } \\
\text { repositories. } \\
\text { open-access.network: Open Access in Computer Science }\end{array}$ \\
\hline & $\begin{array}{l}\text { Journal of Open-Source Software. } \\
\text { https://joss.theoj.org/ }\end{array}$ \\
\hline
\end{tabular}




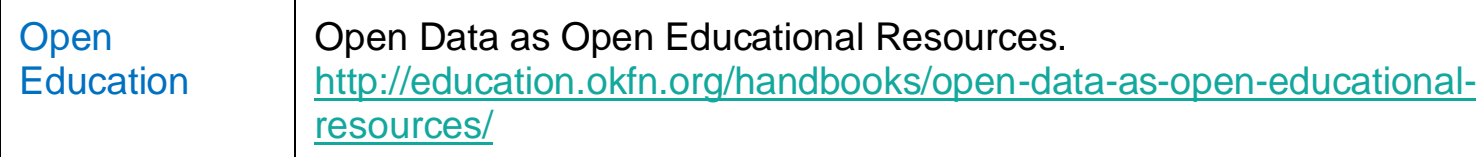

\section{Computational Modelling}

\section{Examples of open research practices}

Open Methods: Nousias, Zacharaki and Moustakas (2020) present AVATREE (https://gitlab.com/LungModelling/avatree), an open-source toolbox in C++ which is a computational modelling framework that generates Anatomically Valid Airway Tree conformations that allows simulations on broncho-constriction in obstructive pulmonary conditions (https://doi.org/10.1371/journal.pone.0230259). It also allows visualisation of spatial probability maps for airway generations projected on CT imaging data and airway tree based on local structure properties. It can be used to simulate broncho-constrictions apparent in pulmonary diseases such as asthma with the aim of improving clinical decision making.

\section{Table of resources}

\begin{tabular}{|l|l|}
\hline $\begin{array}{l}\text { Transparency } \\
\text { category }\end{array}$ & Resources \\
\hline \multirow{1}{*}{ General } & $\begin{array}{l}\text { Open research course. } \\
\text { https://git.fmrib.ox.ac.uk/open-science/computational-models-course }\end{array}$ \\
\cline { 2 - 3 } & $\begin{array}{l}\text { Standards and best practices. } \\
\text { https://blogs.scientificamerican.com/the-curious- } \\
\text { wavefunction/computational-research-in-the-era-of-open-access- } \\
\text { standards-and-best-practices/ }\end{array}$ \\
\cline { 2 - 3 } & $\begin{array}{l}\text { Introduction to computational reproducibility. } \\
\text { https://hal.inria.fr/hal-01358082/document }\end{array}$ \\
\cline { 2 - 3 } & $\begin{array}{l}\text { Tips for reproducible computational workflows. } \\
\text { https://scicomp.aalto.fi/scicomp/zen-of-scicomp/ }\end{array}$ \\
\cline { 2 - 3 } & $\begin{array}{l}\text { The Practice of Reproducible Research, Case Studies and Lessons from } \\
\text { the Data-Intensive Sciences. } \\
\text { http://www.practicereproducibleresearch.org/ }\end{array}$ \\
\hline Open Methods & $\begin{array}{l}\text { Collection of resources. } \\
\text { https://www.comses.net/ }\end{array}$ \\
\hline $\begin{array}{l}\text { Guidelines for modelling and simulation. } \\
\text { https://ieeexplore.ieee.org/document/8247813 }\end{array}$ \\
\hline
\end{tabular}




\begin{tabular}{|l|l|}
\hline Open Data & $\begin{array}{l}\text { Stodden, V., Leisch, F., and Peng, R. D., editors. (2014), Implementing } \\
\text { Reproducible Research, Boca Raton, FL: Chapman \& Hall/CRC } \\
\text { https://osf.io/s9tya/wiki/home/ }\end{array}$ \\
\hline Open Outputs & $\begin{array}{l}\text { Preprint repository. } \\
\text { https://arxiv.org/ }\end{array}$ \\
\hline
\end{tabular}

\section{Artificial Intelligence}

\section{Examples of open research practices}

Open Methods: "Microsoft Research [have] deployed software agents trained with natural language understanding capabilities to continuously scavenge the Web for research artifacts and, from them, extract up-to-date academic knowledge into a graph-based representation called Microsoft Academic Graph (MAG) (Sinha et al., 2015). As the records are from the entire web, MAG equalizes the discoverability of research materials made accessible by the incumbent publishers as well as by individual authors self-archiving at their own websites, potentially making policy initiatives to favour "Gold" over "Green" OA (e.g., Gibbs, 2013) less critical." (https://doi.org/10.3389/fdata.2019.00026)

\section{Table of resources}

\begin{tabular}{|l|l|}
\hline $\begin{array}{l}\text { Transparency } \\
\text { category }\end{array}$ & Resources \\
\hline General & $\begin{array}{l}\text { Implications of openness in Al. } \\
\text { https://www.nickbostrom.com/papers/openness.pdf }\end{array}$ \\
\hline \multirow{3}{*}{ Open Methods } & $\begin{array}{l}\text { Presentation on new tools and services in Al and open research. } \\
\text { https://www.stm- } \\
\text { assoc.org/2018 } 12 \text { 05 STM Week Innovations Jon White.pdf }\end{array}$ \\
\cline { 2 - 3 } & $\begin{array}{l}\text { Recommendations on how to create reproducible Al. } \\
\text { https://www.isi.edu/ gil/papers/gundersen-etal-aimagazine18.pdf }\end{array}$ \\
\cline { 2 - 3 } & $\begin{array}{l}\text { Open data, tasks, and analysis scripts for machine learning. } \\
\text { https://www.openml.org/ } \\
\text { https://arxiv.org/pdf/1402.6013.pdf }\end{array}$ \\
\cline { 2 - 3 } & $\begin{array}{l}\text { Open-source software and tools. } \\
\text { https://openai.com/ }\end{array}$ \\
\hline Open Data & $\begin{array}{l}\text { Comprehensive list of machine learning datasets. } \\
\text { https://lionbridge.ai/datasets/the-50-best-free-datasets-for-machine- } \\
\text { learning/ }\end{array}$ \\
\hline Open Outputs & $\begin{array}{l}\text { Preprint repository. } \\
\text { https://arxiv.org/ }\end{array}$ \\
\hline
\end{tabular}




\section{Methodologies}

\section{Qualitative Research}

\section{Examples of open research practices}

Open Data: "The Qualitative Data Repository (QDR) is a dedicated archive for storing and sharing digital data (and accompanying documentation) generated or collected through qualitative and multi-method research in the social sciences." (https://qdr.syr.edu)

Open Data: Interview transcript data, meeting transcript data. For example, "The Language Technology Group [from the University of Copenhagen] work with transcript data from the Danish Parliament. They publish their data, the Danish Parliament Corpus (2009-2017), in a FAIR (Findable, Accessible, Interoperable, Reusable) way in CLARINDK. Having FAIR data is essential to their field, because without freely accessible data they could not perform their research". (https://howtofair.dk/how-to-fair/\#humanities)

Table of resources

\begin{tabular}{|c|c|}
\hline $\begin{array}{l}\text { Transparency } \\
\text { category }\end{array}$ & Resources \\
\hline \multirow[t]{7}{*}{ General } & $\begin{array}{l}\text { Kapiszewski, D., and Karcher, S. (2019). Transparency in Practice in } \\
\text { Qualitative Research. PS: Political Science \& Politics, 1-7. } \\
\text { https://doi.org/10.33774/apsa-2019-if2he-v2 }\end{array}$ \\
\hline & $\begin{array}{l}\text { Haven, T. L., and Van Grootel, L. (2019). Preregistering qualitative } \\
\text { research. Accountability in Research, } 26 \text { (3), 229-244. } \\
\text { Doi: } 10.1080 / 08989621.2019 .1580147\end{array}$ \\
\hline & $\begin{array}{l}\text { Haven, T. L., Errington, T. M., Gleditsch, K., van Grootel, L., Jacobs, A. } \\
\text { M., Kern, F., ... Mokkink, L. (2020, July 6). Preregistering Qualitative } \\
\text { Research: A Delphi Study. } \\
\text { https://doi.org/10.31235/osf.io/pz9jr }\end{array}$ \\
\hline & $\begin{array}{l}\text { Qualitative Research Pre-registration Template. } \\
\text { https://osf.io/b6xmd/ }\end{array}$ \\
\hline & $\begin{array}{l}\text { Chauvette, A., Schick-Makaroff, K., and Molzahn, A. E. (2019). Open } \\
\text { data in qualitative research. International Journal of Qualitative Methods, } \\
18 . \\
\text { Doi: } 10.1177 / 1609406918823863\end{array}$ \\
\hline & $\begin{array}{l}\text { Mannheimer, S., Pienta, A., Kirilova, D., Elman, C., and Wutich, A. } \\
\text { (2019). Qualitative data sharing: Data repositories and academic } \\
\text { libraries as key partners in addressing challenges. American Behavioural } \\
\text { Scientist, 63(5), 643-664. } \\
\text { https://doi.org/10.1177/0002764218784991 }\end{array}$ \\
\hline & $\begin{array}{l}\text { Qualitative Transparency Deliberations (QTD). } \\
\text { https://www.qualtd.net/ }\end{array}$ \\
\hline
\end{tabular}




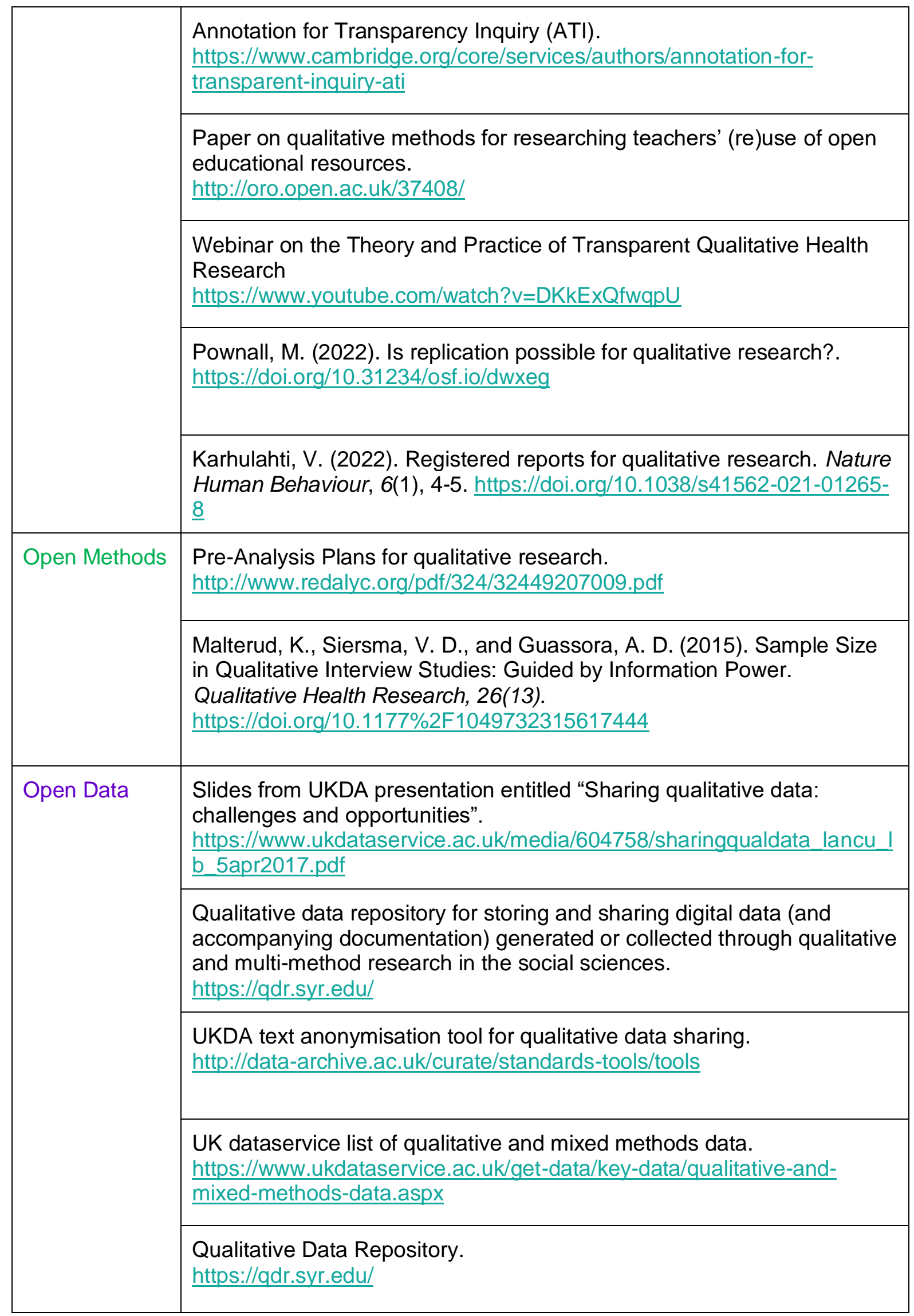




\begin{tabular}{|l|l|}
\hline Open Outputs & $\begin{array}{l}\text { Annotation for Transparent Inquiry (ATI). Tool to annotate passages in } \\
\text { an article, to amplify the text / link to data sources } \\
\text { https://qdr.syr.edu/ati }\end{array}$ \\
\cline { 2 - 3 } & $\begin{array}{l}\text { Mannheimer, S., Pienta, A., Kirilova, D., Elman, C., and Wutich, A. } \\
\text { (2019). Qualitative data sharing: Data repositories and academic } \\
\text { libraries as key partners in addressing challenges. American Behavioral } \\
\text { Scientist, 63(5), 643-664. } \\
\text { https://doi.org/10.1177/0002764218784991 }\end{array}$ \\
\hline
\end{tabular}

\section{Single-Case Design (SCD)}

\section{Examples of open research practices}

Open Methods: Although publication bias has been largely reported from a non-SCD point of view, its existence is not excluded within SCD research, e.g. SCD researchers are also more likely to submit large effect manuscripts (see reference below). Currently, open research practices that aim to reduce this bias include the Single-Case Design Pilot Standards which distinguishes between well-designed and statistically effective judgements of prospective research. (Shadish, W. R., Zelinsky, N. A. M., and Vevea, J. L. (2016). A survey of publication practices of single-case design researchers when treatments have small or large effects. (Journal of Applied Behaviour Analysis, 49, 656-673. https://doi.org/10.1002/jaba.308)

Table of resources

\begin{tabular}{|l|l|}
\hline $\begin{array}{l}\text { Transparency } \\
\text { Category }\end{array}$ & Resources \\
\hline General & $\begin{array}{l}\text { Potential factors explaining statistical accuracy errors in SCD studies } \\
\text { which use visual analysis. } \\
\text { Dart, E. H., and Radley, K. C. (2017). The impact of ordinate scaling on } \\
\text { the visual analysis of single-case data. Journal of School Psychology, } \\
63,105-118 . \\
\text { https://doi.org/10.1016/j.jsp.2017.03.008 }\end{array}$ \\
\cline { 2 - 3 } & $\begin{array}{l}\text { Transparency guide for SCD research - includes preregistration } \\
\text { information. } \\
\text { Cook, B. G., and Johnson, A. H. (2019). Preregistration in Single-Case } \\
\text { Design Research. Exceptional Children, 86(1), 95-112. } \\
\text { https://doi.org/10.1177/0014402919868529 }\end{array}$ \\
\cline { 2 - 3 } & $\begin{array}{l}\text { Dowdy, A., Tincani, M., and Schneider, W. J. (2020). Evaluation of } \\
\text { publication bias in response interruption and redirection: A meta- } \\
\text { analysis. Journal of Applied Behaviour Analysis, 9999, 1-21. } \\
\text { https://doi.org/10.1002/jaba.724 }\end{array}$ \\
\hline
\end{tabular}




\begin{tabular}{|l|l|}
\hline Open Methods & $\begin{array}{l}\text { Lobo, M. A., Moeyaert, M., Baraldi Cunha, A., and Babik, I. (2017). } \\
\text { Single-Case Design, Analysis, and Quality Assessment for Intervention } \\
\text { Research. Journal of neurologic physical therapy: JNPT, 41(3), 187- } \\
197 . \\
\text { https://doi.org/10.1097/NPT.0000000000000187 }\end{array}$ \\
\cline { 2 - 3 } & $\begin{array}{l}\text { Krasny-Pacini, A., and Evans, J. (2018). Single-case experimental } \\
\text { designs to assess intervention effectiveness in rehabilitation: A practical } \\
\text { guide. Annals of physical and rehabilitation medicine, 61(3), 164-179. } \\
\text { https://doi.org/10.1016/j.rehab.2017.12.002 }\end{array}$ \\
\cline { 2 - 3 } & $\begin{array}{l}\text { Johnson, A. H., and Cook, B. G. (2019, July 8). Preregistration in Single- } \\
\text { Case Design Research. } \\
\text { https://doi.org/10.35542/osf.io/rmvgc }\end{array}$ \\
\hline Open Data & $\begin{array}{l}\text { Manolov, R., and Moeyaert, M. (2017). How can single-case data be } \\
\text { analyzed? Software resources, tutorial, and reflections on } \\
\text { analysis. Behavior Modification, 41(2), 179-228. } \\
\text { https://doi.org/10.1177/0145445516664307 }\end{array}$ \\
\hline Open Outputs & $\begin{array}{l}\text { Preprint repositories. } \\
\text { https://edarxiv.org/ } \\
\text { https://psyarxiv.com/ }\end{array}$ \\
\hline
\end{tabular}

\section{Personal Data}

Research data can contain personal data. "Personal data means any information relating to a natural person that is either identified or could be identified by that data (e.g., by reference to an identifier such as a name, an identification number, location data, online identifier or to one or more factors specific to the physical, physiological, genetic, mental, economic, cultural or social identity of that person). Data protection rules always apply wherever personal data is being processed."

(From https://www.openaire.eu/factsheet-personal-data/view-document?|temid=)

Data often contains personal data, particularly in the fields of life and health science, and in disciplines that collect qualitative data. If you are collecting any personal data (even if you are not going to openly share personal data) you must involve your university ethics board and your university General Data Protection Regulation (GDPR) processes. Your university ethics board and GDPR experts are in place to assure that you take the appropriate data protection steps, and that you gain informed consent for all processing of personal data (see the resources table for example consent forms for open data).

If the raw data is unsuitable for sharing, it might be possible to anonymise the dataset, but again check with your university GDPR processes. "Anonymised data are no longer personal data, consequently data protection rules are no longer applicable. Effective anonymisation prevents third parties from re-identifying individuals in anonymised datasets, i.e., associating a record to a natural person by using other sources of information."

(From https://www.openaire.eu/factsheet-personal-data/view-document? Itemid=)

However, anonymisation might not always be possible. That is, protecting participants from being identified and ensuring that their anonymous data cannot be de-identified can be 
problematic, particularly data from rare groups or for qualitative research. Again, check with your university GDPR processes. For example, in qualitative research even if pseudonyms are used it is possible that they could be identified by the details in the qualitative data yet stripping the data too much can make the data of little use to others. In these situations, it might be possible to openly share other outputs from the research such as pre-registering the research protocol or the sharing a research log. Another option is to gain consent from participants for the sharing of personal data, usually on restricted access platforms (e.g. www. databrary.org).

\title{
Examples of open use of personal data
}

Databrary is a restricted access data library specialised for sharing video and audio data of research participant data. Sharing is dependent on participants consenting to the storing of their videos and children's birthdates. "One of Databrary's distinguishing features is that it provides a proven framework for sharing sensitive and identifiable data within a trusted network of authorized researchers."

(From https://databrary.org/about/agreement.html)

\section{Table of resources}

\author{
Resources \\ Databrary consent template. \\ https://databrary.org/support/irb/irb-application.html \\ UK data service example consent forms. \\ https://ukdataservice.ac.uk/learning-hub/research-data-management/ethical- \\ issues/consent-for-data-sharing/documenting-consent/
}

Global kids online research kit provides tools and example consent forms for working with children and schools.

http://eprints.Ise.ac.uk/71299/1/Getting-Started-final-25-Oct-16.pdf

Human Participants - General guidance

https://qdr.syr.edu/guidance/human-participants

\section{Open Research and Open Innovation}

Open research and open innovation have a shared end goal, to enable the research to be used by others, with impact for society. In the context of open innovation, the uptake of innovation could be by means of Intellectual Property Rights. IP can encompass any discovery, invention, document, design or research result that could have commercial value and includes, but is not limited to, algorithms, software, chemical compounds, processes, and data arising from experiments. Patenting your ideas gives licensees the opportunity to protect the commercialisation of inventions from your research until profits are made. Even if you were to seek no royalty payments from the licence you would still need to patent inventions at an early stage in order to give our industry partners the confidence to invest in your inventions and take them to market. 
Inventor warning: If your research will produce Intellectual Property (IP), you must talk to your University Intellectual Property office before embarking on any open research practices for your project. If you have publicly disclosed your idea in any way (pre-registration, preprints, publication of a paper in a journal, publishing abstracts, presenting at a conference, certain grant applications are made public) then it will not be possible to obtain valid patent protection for that research.

\title{
Examples of open innovation practices
}

DRIVE (Digital Research Innovation Virtual Environments, https://www.goshdrive.com/about) is run by Great Ormond Street Hospital (GOSH). GOSH are using DRIVE to share their historic, current, and future data. They invite academics and industry to work on their datasets within the DRIVE environment and share the methodologies that have been used as well as results. The sharing of methods both speeds up innovation, but also cross-fertilises ideas. For anyone working on undisclosed methods a private workspace can be created until disclosure is appropriate.

\section{Table of resources}

\author{
Resources \\ Showcase of projects that have used DRIVE data. \\ JRC report on IPRs, technology transfer and open science, "there are no incompatibilities \\ between IPRs and Open Science. On the contrary the IPRs framework, if correctly defined \\ from the onset, becomes an essential tool to regulate open science and ensure that the \\ efforts from different contributors are correctly rewarded." \\ https://publications.jrc.ec.europa.eu/repository/bitstream/JRC106998/kj1a28661enn.pdf
}

The OSPP also calls for "the right balance between Open Science, the potential to maximize the use and re-use of research data and outputs, IPR, and private companies' competitiveness" to be promoted, stating that it must become a central feature of a shared research knowledge system. The report adds that "There are limits to openness and these must be acknowledged and taken into account as the system changes."

https://ec.europa.eu/research/openscience/pdf/ec rtd ospp-final-report.pdf

EARTO Paper: Towards a Balanced Approach Between IPRs and Open Science Policy. https://www.earto.eu/wp-content/uploads/EARTO-Paper-Towards-a-Balanced-ApproachBetween-IPRs-and-Open-Science-Policy-Final.pdf

\section{Open Research and Co-Production}

Co-production is an approach to research which emphasises involving stakeholders and end users of research in a significant way. It cuts across many disciplines and methodological schools and is of increasing popularity. The interaction between co-production and Open Research practices is worth paying special attention to because of the potential conflicts between them.

Co-production means different things in different places. We use it here in a broad fashion to refer to research approaches which involve stakeholders and end users in at least one of the following: identification and prioritisation of research aims and purpose; design of research 
methods and overall study design; data collection; analysis and interpretation of findings; and dissemination and communication of research. We are not referring here to research which simply involves a small element of knowledge exchange or dissemination.

Whilst co-production can often be interlinked with open research, co-production can create a number of potential constraints on a researcher's ability to practice open research. Making outputs open access, or public, can be difficult where research is on private, confidential, or sensitive information or topics. Similarly, some research may involve classified, sensitive or military information, software or technology, which may be deemed to be "strategic" or "dual use" for the purposes of Export Control. In these circumstances, any information, software, or other material placed in a publicly accessible archive must comply with the host country's Export Control laws. For the UK, advice on this can be found at:

https://www.gov.uk/government/organisations/export-control-organisation

Even where the material is not sensitive in any way, partners may have different expectations about how outputs are shared and whether they should be public or not. Equally, co-produced outputs such as data and code may be difficult to share openly when they are jointly owned with others. The practice of pre-registration of research questions and analysis plans may simply not make much sense in the face of a co-produced, iterative, non-linear and emergent research process - processes which often have shifting goals.

So, what should researchers consider when conducting co-produced research but also wanting to practice open research? First, we would strongly recommend having a clear plan and agreement with partners as to what can be published and what, if any, sign-off or agreement partners need to have. If a formal collaboration agreement or non-disclosure agreement is required, be sure to involve your University legal team in this - they will need to approve and sign agreements on your behalf. If you want to use a pre-registration approach, this can still be done, but this could describe the approach to co-production, rather than the specific research projects within it. Writing a pre-registration document may also help you crystallise your plans for iterating and adapting to different stages of the research.

\section{Examples of co-produced practices}

1. "In Kokonoe Town, part of the Aso-Kuju National Park, southwest Japan, an alien invasive plant (Rudbeckia laciniata L.) was recently introduced and quickly had a negative influence on local biodiversity. Local stakeholders, including governmental agencies, tourist associations, and naturalists, were fully aware of this problem. To address this ecological issue, one of the authors (Osawa) developed a data collection tool, and local civic participants used it to collect geospatial data for this species. These data were used to develop a management plan, which successfully reduced conflicts among stakeholders. The data were disclosed as open data in a scholarly publication. In this project, expert ecologists and non-experts contributed equally. In this collaboration, non-expert participants, as well as experts, were able to check and validate data, and even monitor the status of the plant." (From https://doi.org/10.1186/s12961-019-0432-3)

2. Recent examples of co-produced research at the University of Surrey can be found in the work of the ESRC Centre for the Evaluation of Complexity Across the Nexus (CECAN, https://www.cecan.ac.uk) hosted in the Sociology department. CECAN works closely with partners from central government and the private sector to develop and support improved policy evaluation and design. Many of the projects CECAN undertakes are co-produced with government departments to directly address their policy evaluation and design needs and objectives. This has allowed CECAN's work to have great impact and enjoy an engaged audience, however it has also caused challenges in relation to Open Research. The most obvious example is the projects which have been on such sensitive subjects that a non-disclosure agreement was required by partners. Great care was taken to allow a 
balance in these agreements such that research could still be published where appropriate and with agreement.

Table of resources

\section{Resources}

ORION (Open Responsible research and Innovation to further Outstanding Knowledge) include co-creation projects as part of their four-year project, as part of their aim to widen participation and collaboration in research.

https://www.orion-openscience.eu/activities/co-creation

ORION menu of co-creation methods.

https://www.orion-openscience.eu/public/2018-

05/D3.1\%20Menu\%20of\%20Creation\%20Tools.pdf

Oliver, K., Kothari, A. and Mays, N. (2019). The dark side of coproduction: do the costs outweigh the benefits for health research? Health Research Policy and Systems, 17, 33.. https://doi.org/10.1186/s12961-019-0432-3

Kondo Y, Miyata A, Ikeuchi U et al. (2019). Interlinking open science and communitybased participatory research for socio-environmental issues. Current Opinion inEnvironmental Sustainability, 39, 54-61.

https://doi.org/10.1016/J.COSUST.2019.07.001

Factsheet on the use of personal data.

https://www.openaire.eu/factsheet-personal-data/view-document

This work is licensed under CC BY 4.0 